\title{
Using morphometric and geomorphic indices to assess Western São Francisco Craton neotectonic traces
}

Uso de índices morfométricos e geomórficos na análise de traços neotectônicos no setor ocidental do Cráton do São Francisco

\author{
Mário Teixeira Rodrigues Bragança*1 $\varangle\left(\mathbb{D}\right.$, Luiz Fernando de Paula Barros ${ }^{2} \bowtie(1)$ \\ Déborah de Oliveira1 $₫$ (D)
}

\author{
${ }^{1}$ Programa de Pós-Graduação em Geografia Física, Departamento de Geografia, Faculdade de \\ Filosofia, Letras e Ciências Humanas, Universidade de São Paulo, São Paulo, SP, Brasil \\ 2 Programa de Pós-Graduação em Geografia, Departamento de Geografia, Instituto de \\ Geociências, Universidade Federal de Minas Gerais, Belo Horizonte, MG, Brasil \\ E-mail: luizbarros@ufmg.br (LFPB); debolive@usp.br (DO) \\ *E-mail para correspondência: mario.teixeira@usp.br
}

\begin{abstract}
Recently, geomorphometric properties of river networks and catchments have been described and applied as an efficient tool in the investigation of the landforms' response to neotectonics. Geometric parameters of the Cotovelo River catchment extracted from an Alos-Palsar digital elevation model were used to compute morphometric and geomorphic indices to investigate whether the bedrock structure and recent active tectonics influence the local drainage network. The Cotovelo catchment is situated in the Middle to Upper Proterozoic western foreland basin of the São Francisco craton, in northwestern Minas Gerais, Southeastern Brazil; it is presumed to be a stable piece of earth's crust. The automatically generated streams were processed at the sub-catchment scale to calculate the hypsometric integral, relief ratio, stream frequency, and drainage density morphometric indices as well as supported a geomorphic study based on the basin shape, asymmetry factor, valley floor width-to-height ratio, mountain front sinuosity, transverse topographic symmetry factor, and stream-length gradient index. Achieved results revealed recent and lowrate tectonic activity and structural control on the fluvial morphology. Prominent knickpoints, aligned with mapped fault scarps, disclose straight erosive fronts away from stratigraphic borders, indicating these features are unrelated to lithological changes. Despite the catchment location, the area exhibits impressive fluvial anomalies, and dissection occurs preferentially along ancient faults and fractures densely occurring in the rocky strata. Channel parallelism in context of medium to high relief and steep slopes, remarkably structurally drive fluvial dissection, asymmetric and elongated drainage catchments, and aligned landforms suggest neotectonic influence on the drainage network.
\end{abstract}

Keywords: Morphotectonics; drainage network; channel morphology; knickpoints.

Resumo: Recentemente, parâmetros geomorfométricos dos canais fluviais e de bacias hidrográficas têm sido utilizados como uma ferramenta eficiente na investigação da resposta do relevo à neotectônica. Parâmetros geométricos da bacia hidrográfica do Ribeirão Cotovelo extraídos de um modelo digital de elevação Alos-Palsar foram usados para calcular índices geomorfométricos, com o propósito de verificar se a tectônica recente influencia a organização da drenagem local. A bacia do Ribeirão Cotovelo está situada na bacia antepaís Mesoneoproterozoica ocidental do Cráton do São Francisco, no Noroeste do Estado de Minas Gerais, Sudeste do Brasil, portanto, um ambiente crustal presumivelmente estável. Canais gerados automaticamente foram processados e forneceram indices morfométricos como densidade de drenagem, integral hipsométrica, razão de relevo e frequência de rios, bem como subsidiaram um estudo geomórfico baseado no fator de forma da bacia, fator de assimetria, relação largura-altura do fundo do vale, sinuosidade da frente da montanha, fator de simetria topográfica transversal e relação declividadeextensão. Os resultados apontam um controle tectônico e estrutural da morfologia fluvial. Knickpoints proeminentes, alinhados com escarpas de falhas mapeadas revelam frentes erosivas retilineas, distantes de contatos estratigráficos, portanto, não relacionadas às variações litológicas. Apesar da localização da bacia, os canais fluviais exibem anomalias impressionantes e a dissecção ocorre preferencialmente ao longo de paleoestruturas e estratos rochosos densamente fraturados; o paralelismo dos canais em um contexto de 
relevo ondulado e vertentes ingremes, o forte condicionamento estrutural da dissecação fluvial, bacias assimétricas e alongadas e relevos alinhados sugerem controle neotectônico ativo da rede de drenagem.

Palavras-chave: Morfotectônica; rede de drenagem; morfologia fluvial; knickpoints.

\section{Introduction}

Morphometric analysis of catchments and drainage networks is a useful method to identify the relationship of various regional physiographic aspects (SUKRISTIYANTI et al., 2018), notably the relationship among lithology, structures, and landforms. Thus, numerous studies have been conducted on direct or indirect morphometric analyses, particularly to investigate the evidence of recent tectonic activities (BULL; MCFADDEN, 1977; ROCKWELL et al., 1985; WELLS et al., 1988; KELLER; PINTER, 2002; AZOR et al., 2002; SILVA et al., 2003; EL HAMDOUNI et al., 2008).

These studies have become easily taught and proved to be operative by using a variety of spatial resolution digital elevation model (DEM) data, owing to advances in geographic information system (GIS) technology and tools and noticeable Open Source GIS (QGIS Development Team, 2021). Notably, new freely available and accessible digital spatial data are becoming attractive for more public users (GROHMANN, 2004), and digital terrain data processing supports morphometric analysis accurately, quickly, and inexpensively (GROHMANN et al., 2007). Therefore, DEM processing is an advantageous tool for exploratory analysis or in areas that do not have detailed topographic maps.

Worldwide, these procedures have been widely applied to tectonically active regions, such as the Himalayan Arc (SEEBER; GORNITZ, 1983), Nicoya Peninsula in Costa Rica (HARE; GARDNER, 1984), Mexican Volcanic Belt (RAMÍREZ-HERRERA, 1998), South and Southern Spain (SILVA et al., 2003; EL HAMDOUNI et al., 2008; PEDRERA et al., 2009; PÉREZ-PEÑA et al., 2010). In Brazil, the morphometry of fluvial systems is one of the most common themes in fluvial geomorphology (BARROS; REIS, 2019) and the previously referenced techniques have largely been applied to investigate the correlation between geological features and the physiography of river valleys (ETCHEBEHERE et al., 2006; ROSSETTI et al., 2008; SOUZA; ROSSETTI, 2011; FUJITA et al., 2011; BARBOSA; FURRIER, 2017). Moreover, morphometric and geomorphic indices were trained in Brazil in assessments of development of drainage systems and discrimination of ductile and brittle tectonics (ALVES et al., 2014), progress and growth of river catchments (BARBOSA; FURRIER, 2011), changes in river profiles (BARBOSA et al., 2013), identification and demarcation of morphotectonic features (CAMOLEZI et al., 2012), litho-structural and tectonic zoning (CHERÉM et al., 2011), and effective detection of neotectonics (LIMA; FURRIER, 2014; ALVES; ROSSETTI, 2017).

This research aims to assess whether the western São Francisco deformed cratonic foreland basin (CAMPOS; DARDENNE, 1997a; Reis et al., 2016) provided sufficient evidence to demonstrate recent tectonic activity in a rigid crustal environment. Therefore, the Cotovelo River catchment was used as the study area. It lies over the western Neoproterozoic foreland basin of the São Francisco Craton (ALKMIM; MARSHAK, 1998; CHANG et al., 1987) in the Brazilian Atlantic Shield and is considered a stable piece of crust (CETEC, 1983; VALADÃO, 1998; REIS et al., 2017), despite the large amount of fluvial and landscape anomalies observed in this area by satellite images and topographic data.

\section{Study area}

The Cotovelo River and its catchment is spread entirely in the municipality of Brasilândia de Minas, Minas Gerais State, southeastern Brazil (Figures 1A and 1B). The river springs in the Canastra Plateau (the local place name of the Paracatu-Urucuia drainage divide) and flows to the southeast, until it meets the lowvalley floodplain, where it changes its direction to the southwest in a $90^{\circ}$ turn (Figure 1C), a feature that justifies its name ("elbow" in English). The hydrological catchment has an area of $788.1 \mathrm{~km}^{2}$ and the river is $81,891 \mathrm{~m}$ in length; the altitude varies between 743 meters above sea level (masl) at the source and 497 masl at the outlet. 


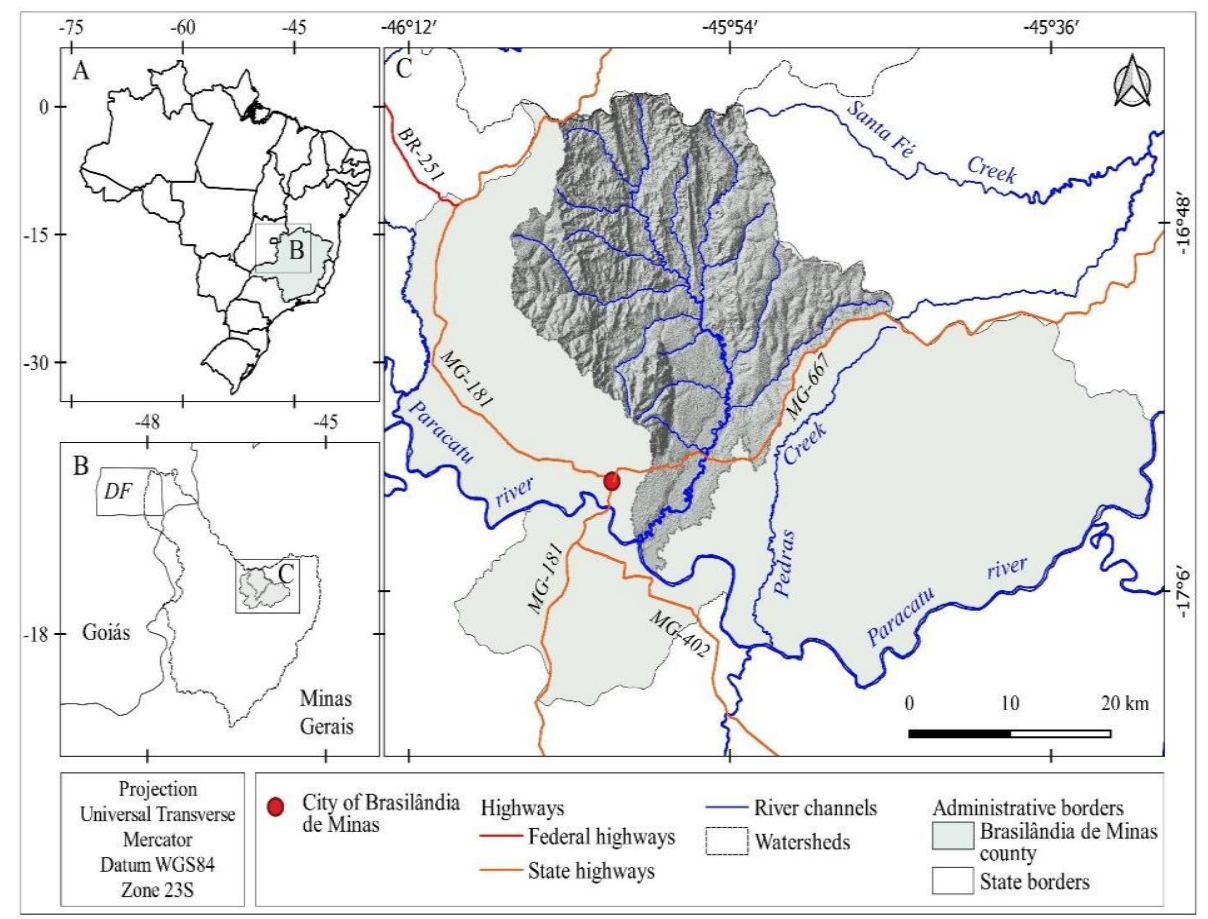

Figure 1: A) Emplacement of Paracatu river catchment in the national context; B) Position of the Municipality of Brasilândia de Minas in the northwestern Minas Gerais State and inner Paracatu catchment; C) Hillshade of the Cotovelo catchment and their tributaries inserted in the Municipality of Brasilândia de Minas. Modified from Prodemge. Minas Gerais State digital cartographic sheets.

The regional geological setting comprises two main sedimentary and metasedimentary sequences (Figure 2): the Neoproterozoic-Ediacaran Bambuí Group and the Phanerozoic strata (CAMPOS; DARDENNE, 1997; CPRM, 2003a; 2003b; REIS et al., 2017). The Bambuí Group is essentially composed of siliciclastic lithologies, such as sandstones, siltstones, argillites, limestones, marls, and conglomerates (CAMPOS; DARDENNE, 1997a; PEDROSA-SOARES et al., 1994; REIS et al., 2017), setting up locally in the Três Marias, Serra da Saudade, and Lagoa do Jacaré formations (DARDENNE, 1978; SCHOBBENHAUS et al., 1985). The Phanerozoic coverages in the study area consists of sandy and clastic successions from the Middle to Upper Cretaceous, integrated in the Areado and Urucuia Group, along with the Neocenozoic unconsolidated sandy, silty, and clayey detrital-regolith, colluvium and alluvium coverages encompassed by the Chapadão Formation (CETEC, 1983; CPRM, 2003a, 2003b; SGARBI et al., 2001). A remarkable feature to be highlighted is the presence of the Precambrian NNW-SSE shear zone (CPRM, 2003a; 2003b) and a thrust and folded zone correlated to the Paraopeba sub-group, which comprises the Sete Lagoas, Serra de Santa Helena, Lagoa do Jacaré, and Serra da Saudade formations of the Bambuí Group (SCHOBBENHAUS et al., 1984).

Two regional-scale geomorphological units were described in the area as broad erosive features: the São Francisco Plateau and the São Francisco Depression (CETEC, 1983, 1981). The São Francisco Plateau describes a tableland morphology with elevations ranging from 700 masl to 860 masl. Regionally known as "chapadas", these landforms correspond to wide and extensive drainage divides, covered by sandy, locally lateritic sediments, delimited for erosive vertical scarps (CETEC 1983). The São Francisco Depression comprises a broad, lowered, undulated, pediplanated, sedimentary area delimited by low escarpments along the main streams; altitudes vary from 480 masl to 560 masl (CETEC, 1983, 1981).

The Cotovelo River is a left bank barbed tributary (HAREL et al., 2019) of the Paracatu River and its catchment lies over the São Francisco Plateaus (CETEC, 1981; 1983) comprising three main geomorphological landscapes. First is a tableland-like elevated plateau sculpted over predominant Carboniferous-Permian (Santa Fé Group) and Cretaceous (Areado and Urucuia Groups) sandy and sandysilty strata, delimited by highly dissected scarps. Second is a terrace level, conglomeratic, flat-floored landscape, covered by sandy and silty-sand materials, positioned at both margins of the low-valley floodplain and in the southern divides. Third is a wide floodplain, associated with Upper Pleistocene and Holocene alluvial and colluvial sandy, silty, and clayey sediments (CETEC, 1981; CPRM, 2003b). 


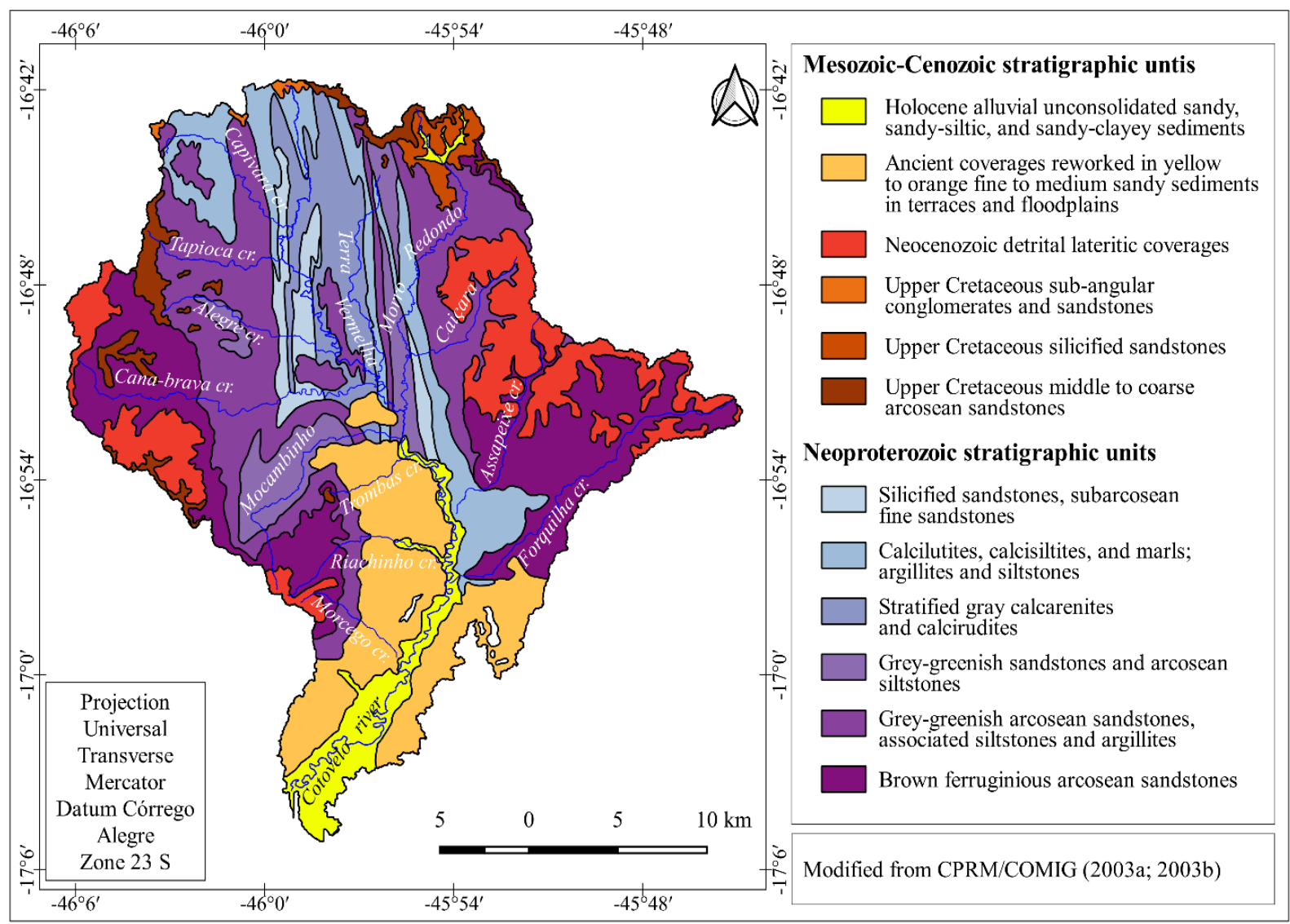

Figure 2: Simplified geological map of the Cotovelo catchment (Modified from CPRM, 2003a; 2003b)

Presently, convective systems explain the regional concentration of rain during the summer season (December-January-February) in the São Francisco catchment (NIMER, 1957; MARENGO et al., 2012), with an average monthly temperature of $18^{\circ} \mathrm{C}$ and annual rainfall of 1,500-2,000 mm (BRASIL, 1992).

\section{Methods}

To accomplish the objective, a Phased Array type L-band Synthetic Aperture Radar digital elevation model, Alos-Palsar DEM (ASF-DAAC, 2015) with $12.5 \mathrm{~m}$ per pixel of spatial resolution was processed to obtain the geometric parameters of the rivers and their catchments, using resources of GRASS GIS (Geographic Resources Analysis Support System Geographic Information System; GRASS GIS community, 2021) and SAGA GIS (System for Automated Geoscientific Analyses Geographic Information System; Conrad et al., 2015), embodied into QGIS 3.14 (QGIS Development Team, 2019), such as r.basin, r.watershed, r.water.outlet, etc. (Grohmann, 2004; Grohmann et al., 2007; 2011). Some parameters and basic unprocessed data were obtained using the database functionalities of MapInfo Professional 10.0. Finally, Microsoft Excel electronic spreadsheet was used for the simplest arithmetic operations for practical reasons. These data were used in the computation of morphometric and selected geomorphic indices, and the approach to data generation and processing at the catchment scale was appropriate and very efficient, providing a large automatically generated database that can avoid inhomogeneities.

Conventional morphometric indices processed and analyzed were stream order (STRAHLER, 1952; 1957), stream number (HORTON, 1932; 1945), stream length (HORTON, 1932; 1945), stream frequency (SMITH, 1950; FREITAS, 1952), hypsometric integral (STRAHLER, 1952), relief ratio (SCHUMM, 1956), and drainage density (HORTON, 1932; SMITH, 1950).

Six geomorphic indices were chosen to assess the area: the asymmetric factor, the drainage basin shape, the valley floor width-to-height ratio, the transverse topographic symmetry factor, the mountain front sinuosity, and the stream-length gradient index.

The asymmetric factor (HARE; GARDNER, 1985) quantifies the displacement of the channel from the middle of the catchment due to tilting or tectonic reason, defined by the equation 


$$
A f=100\left(\frac{A r}{A t}\right)
$$

Eq. 1

where $A r$ is the area of the catchment to the right (facing downstream) of the trunk stream and $A t$ is the total area of the drainage basin.

The drainage basin shape ratio (SCHUMM, 1956; CANNON, 1976) quantifies the shape of a catchment, while relating their longest and widest points, calculated as follow

$$
B s=B l / B w
$$

Eq. 2

where $B l$ is measured from the springs to the outlet, and $B w$ is the measure of the widest point of the catchment.

The valley floor width-to-height ratio (BULL; MCFADDEN, 1977) is used to discriminate V-shaped dissected and U-shaped flat-floored valleys, by means of the equation

$$
V f=2 V f w /[(E l d-E s c)+(E r d-E s c)
$$

where $V f w$ is the valley floor width, Eld and Erd are elevations to the left and right drainage divide, and Esc is the valley floor elevation.

The transverse topographic symmetry factor (COX, 1994) evaluates the amount of asymmetry of a river within a catchment, as a consequence of lateral tilting that may be correlated to tectonics (COX, 1994; SALVANY, 2004), computed as

$$
T=D a / D d
$$

Eq. 4

where $D a$ was computed as the distance from the current channel to the catchment middle line; $D d$ is the distance from the water divide to the catchment middle line. $T$ Values vary between 0 in symmetric catchments and 1 in asymmetric catchments.

The mountain front sinuosity (BULL; MCFADDEN, 1977) evaluates the tectonic activity along mountain fronts, that is, the scarp created by a vertical displacement of a fault and the sedimentary basin at its piedmont; it is computed as

$$
S m f=L m f / L s
$$

where Lmf is the length of front or scarp considered, along a selected contour, and Ls is the straight-line length of the same front or scarp.

With respect to the $S m f$, it must be highlighted that eight different mountain fronts were selected in a visual-based inspection of high-resolution satellite images, from a hypsometric map, and field reconnaissance, for a particular assessment. They are bounded by sharp impressive scarps and with geomorphological significance, being seven located in the right margin and one in the left margin of the Corovelo River. Seven of these cliffs are oriented N-S, roughly parallel to the Cotovelo riverbed; only one scarp is oriented toward the northwest, by the N-NE face of the Boqueirão Plateau.

The stream-length gradient index (HACK, 1973) assesses the deviation of part of a fluvial profile from the theoretical concave longitudinal profile, corrected for the distance to the drainage divide (VIVEEN et al., 2012), calculated as

$$
S L=\Delta H / \Delta L) * L
$$

where $\Delta H$ is the difference in height of the selected channel reach, $\Delta L$ is the length of this reach, and $L$ is the length of the entire channel upstream the halfway point of this reach.

The SL-index was obtained for the Cotovelo River, eleven tributaries and one sub-tributary, using DEM data and QGIS functionalities for successive individual reach values from the automatically generated 
drainage network, for river lengths ranging from $6,100 \mathrm{~m}$ to $82,000 \mathrm{~m}$. For each river, the SL-index values were averaged using a moving window of seven neighbors, which corrected narrow spikes and smoothed out the final curve.

\section{Results and discussion}

Sensitive to sudden variations in topography (PERUCCA et al., 2014; MANJORO, 2015), rivers have been the most used indicators in exploratory studies of recent tectonic activity (DEMOULIN, 2011; MARPLE; TALWANI, 1993; PÉREZ-PEÑA et al., 2009; RHEA, 1989; SOUGNEZ; VANACKER, 2011). In stable platforms, where tectonic activity is noticeably less expressive than in active zones, rivers tend to respond more quickly to barely noticeable deformations in the topography. Thus, small variations in the fluvial morphology or behavior of the fluvial channel may suggest signs of crustal movement (OUCHI, 1985).

A full drainage network and a row geometric database (Table 1) automatically derived from the DEM processing routines provided support for creating a basic map of the Cotovelo catchment, encompassing their main tributaries, and is the starting point for posterior geometric, morphometric, and geomorphic calculations and analyses. Subsequently, these data were used to calculate morphometric parameters (Tables 2), morphometric indices (Table 3), and geomorphic indices (Table 4), which supported the spatial and hydrological analysis of the entire Cotovelo catchment and their sub-catchments. Moreover, linear morphometric parameters were computed for rivers and sub-catchments, relating to channel patterns, drainage density, river incision, and landscape dissection.

Table 1: Basic geometric data of the Cotovelo River, Cotovelo catchment, and their tributaries and subcatchments.

\begin{tabular}{lccccccccccc}
\hline Catchments & $\mathbf{S}_{\text {ord }}{ }^{(1)}$ & $\mathbf{h}^{(2)}$ & $\mathbf{H}^{(3)}$ & $\mathbf{\Delta \mathbf { h } ^ { ( 4 ) }}$ & $\mathbf{L}^{(5)}$ & $\boldsymbol{P}^{(6)}$ & $\mathbf{n}^{(7)}$ & $\mathbf{A}^{(8)}$ & $\mathbf{L t}^{(9)}$ & $\mathbf{L c d}^{(10)}$ & $\mathbf{L d}^{(11)}$ \\
\hline Cotovelo & 7 & 481 & 830 & 349 & 60,690 & 208,800 & 7,194 & 788.10 & $2,253,565$ & 43,300 & 43,460 \\
Forquilha & 5 & 504 & 739 & 235 & 23,460 & 66,780 & 930 & 92.37 & 262,713 & 18,600 & 19,200 \\
Assapeixe & 5 & 509 & 742 & 233 & 15,760 & 41,730 & 394 & 39.37 & 118,825 & 12,200 & 12,400 \\
Caiçara & 5 & 533 & 791 & 258 & 10,910 & 32,610 & 291 & 32.17 & 88,746 & 8,500 & 8,900 \\
Morro Redondo & 6 & 522 & 849 & 327 & 25,060 & 67,210 & 752 & 82.66 & 232,291 & 17,400 & 19,000 \\
Terra Vermelha & 4 & 527 & 809 & 282 & 15,590 & 33,620 & 246 & 26.50 & 72,957 & 11,700 & 12,100 \\
Capivara & 5 & 557 & 845 & 288 & 12,650 & 35,230 & 363 & 42.42 & 115,705 & 8,300 & 10,000 \\
Tapioca & 4 & 518 & 819 & 301 & 10,210 & 26,310 & 139 & 16.12 & 41,018 & 7,800 & 8,000 \\
Alegre & 4 & 525 & 816 & 291 & 12,510 & 31,940 & 230 & 25.82 & 66,283 & 10,000 & 10,900 \\
Cana-brava & 6 & 504 & 781 & 277 & 23,600 & 71,750 & 1,040 & 113.40 & 300,937 & 18,100 & 17,900 \\
Mocambinho & 5 & 523 & 772 & 249 & 1,770 & 45,870 & 503 & 52.71 & 144,136 & 11,000 & 12,130 \\
Trombas & 4 & 533 & 791 & 258 & 6,108 & 18,050 & 73 & 9.15 & 29,689 & 5,000 & 5,220 \\
Riachinho & 4 & 518 & 790 & 272 & 12,510 & 32,170 & 239 & 24.69 & 65,138 & 9,200 & 9,520 \\
\hline
\end{tabular}

Note: Data source: Digital processing of the ALOS-PALSAR DEM. ${ }^{(1)}$ Sord: Stream order (Strahler, 1952); ${ }^{(2)} \mathrm{h}$ : outlet altitude; ${ }^{\left({ }^{3)}\right.} \mathrm{H}$ : Springs altitude; ${ }^{(4)} \Delta \mathrm{h}$ : topographic gradient; ${ }^{(5)} \mathrm{L}$ : channel length $(\mathrm{m}) ;{ }^{(6)} \mathrm{P}$ : catchment perimeter $(\mathrm{m}) ;{ }^{(7)} \mathrm{n}$ : total number of channels; ${ }^{(8)} \mathrm{A}$ : catchment area $\left(\mathrm{km}^{2}\right)$; ${ }^{(9)} \mathrm{Lt}$ : total length of the drainage channels $(\mathrm{m}) ;{ }^{(10)} \mathrm{Lcd}$ : vector distance between the channel springs and the outlets $(\mathrm{m}) ;{ }^{(11)} \mathrm{Ld}$ is the vector distance between the catchment extreme points $(\mathrm{m})$.

Because Cotovelo has 12 tributaries with remarkable characteristics suitable for the proposed geomorphological investigation, analytical descriptions of the results are presented from a comparative point of view.

Based on the stream order, the Cotovelo catchment was classified as a seventh-order catchment, and the order of their 12 main longest tributaries varied from $4^{\text {th }}$ to $6^{\text {th }}$ (Table 2). It is noticeable that a higher number of streams is concentrated in the $2^{\text {nd }}$ order streams.

The total stream length is higher in the $1^{\text {st }}$ order and very low in the $2^{\text {nd }}$ order. Then, it increases again in the $3^{\text {rd }}$ order and progressively decreases until the $7^{\text {th }}$ order (Table 2). Deviations in these parameters can be a consequence of changes in lithology, - a characteristic feature of the NNW-SSE shear zone (CPRM; 2003a; 2003b) - , high relief or steep slopes that control the channel shape and channel network of rivers (GIAMBONI et al., 2005), recurrent factors inside the Cotovelo catchment. 
Table 2: Morphometric parameters of the entire Cotovelo River drainage network: stream order, number, and length: absolute and relative values

\begin{tabular}{ccccc}
\hline \multirow{2}{*}{ Channel order } & \multicolumn{2}{c}{ Channels } & \multicolumn{2}{c}{ Stream length } \\
\cline { 2 - 5 } & Number & Percentage (\%) & Length $(\mathbf{k m})$ & Percentage (\%) \\
\hline $1^{\text {st }}$ & 3,613 & 35.5 & 1,176 & 67.8 \\
$2^{\text {nd }}$ & 4,694 & 46.0 & 55 & 3.2 \\
$3^{\text {rd }}$ & 901 & 8.8 & 254 & 14.6 \\
$4^{\text {th }}$ & 484 & 4.7 & 136 & 7.8 \\
$5^{\text {th }}$ & 295 & 2.9 & 75 & 4.3 \\
$6^{\text {th }}$ & 116 & 1.1 & 3 & 0.2 \\
$7^{\text {th }}$ & 97 & 1.0 & 36 & 2.1 \\
\hline
\end{tabular}

The hypsometric integral values (HI) for the studied catchments ranged from 0.19 to 0.53 (Table 3). Lower HI values indicate old and more eroded areas, and high HI values suggest young and less eroded areas (EL HAMDOUNI et al., 2008). Three specific trends were observed in this study: first, six catchments yielded HI values under 0.40 (Cotovelo, Morro Redondo, Terra Vermelha, Mocambinho, Trombas, and Riachinho creeks); second, five catchments yielded intermediate $\mathrm{HI}$ values $(0.40 \leq \mathrm{HI}<0.50)$ (Capivara, Tapioca, Forquilha, Alegre, and Cana-brava); finally, two catchments produce higher HI values (HI $\geq 0.50)$ (Assapeixe and Caiçara). Except for the Cana-brava creek, the other courses drain smaller catchments, and the HI values indicate that streams flow over a resistant lithology. Notably, the HI values for Assapeixe and Caiçara creeks indicated active dissection, maybe rejuvenated areas; these results are consistent with analogous of the Araripe and Paraíba sedimentary basins, where HI > 0.50 were used to select erosion-prone sub-catchments and support the hypothesis of neotectonic activity in a composite index (ANDRADES FILHO; ROSSETTI, 2015; OLIVEIRA et al., 2018).

The relief ratio $(\mathrm{Rr})$ indicates a variable scenario among the Cotovelo catchment tributaries $(\mathrm{Rr}<0.042)$; in general, low values suggested an intensively dissected landscape and low possibility of intense and fast floods. However, the Mocambinho stream presents a very discordant result (0.141), showing steeper slopes shaped by active erosional processes.

The stream frequency $(\mathrm{Sf})$ value of Cotovelo catchment and their sub-catchments range from $8.0 \mathrm{~km} / \mathrm{km}^{2}$ to $10.1 \mathrm{~km} / \mathrm{km}^{2}$, which can indicate the predominance of an impervious or less permeable and resistant sedimentary and metasedimentary dominant siltstone and argillite (Serra da Saudade and Lagoa do Jacaré formations) and fine to medium sandstones (Três Barras Formation) rock strata, associated to an undulated or hilly dissected landscape, with a higher and coarse (Smith, 1950) drainage density $\left(2.5 \mathrm{~km} / \mathrm{km}^{2}\right.$ to 3.2 $\mathrm{km} / \mathrm{km}^{2}$ ). These features fit the sedimentary and metasedimentary rock strata and confirm the characteristic geological heterogeneity of the area. In addition, high values of $\mathrm{Dd}\left(\mathrm{Dd}>2.50 \mathrm{~km} / \mathrm{km}^{2}\right)$ correlated well to reactivated structures and rejuvenated erosive processes along weaker lines and tilted blocks, probably due to neotectonic activity (HIRUMA; PONÇANO, 1994).

Table 3: Hypsometric integral, relief ratio, stream frequency, and drainage density of the Cotovelo catchment and channel, along with their sub-catchments and respective channels

\begin{tabular}{lcccc}
\hline Catchments & HI & $\mathbf{R r}^{(2)}$ & $\mathbf{S f}^{(3)}$ & $\mathbf{D d}^{(4)}$ \\
\hline Cotovelo & 0.19 & 0.006 & 9.1 & 2.9 \\
Forquilha & 0.44 & 0.010 & 10.1 & 2.8 \\
Assapeixe & 0.53 & 0.015 & 10.0 & 3.0 \\
Caiçara & 0.50 & 0.024 & 9.0 & 2.8 \\
Morro Redondo & 0.31 & 0.013 & 9.1 & 2.8 \\
Terra Vermelha & 0.25 & 0.018 & 9.3 & 2.8 \\
Capivara & 0.47 & 0.023 & 8.6 & 2.7 \\
Tapioca & 0.47 & 0.029 & 8.6 & 2.5 \\
Alegre & 0.42 & 0.023 & 8.9 & 2.6 \\
Cana-brava & 0.37 & 0.012 & 9.2 & 2.7 \\
Mocambinho & 0.26 & 0.141 & 9.5 & 2.7 \\
Trombas & 0.21 & 0.042 & 8.0 & 3.2 \\
Riachinho & 0.34 & 0.022 & 9.7 & 2.6 \\
\hline
\end{tabular}

Note: ${ }^{(1)} \mathrm{HI}$, hypsometric integral; ${ }^{(2)} \mathrm{Rr}$, relief ratio $(\Delta \mathrm{h} / \mathrm{L}) ;{ }^{(3)} \mathrm{Sf}$, stream frequency $(\mathrm{n} / \mathrm{A}) ;{ }^{(4)} \mathrm{Dd}$, drainage density $(\mathrm{Lt} / \mathrm{A})$. 
Figure 3 presents the mapped results of the geomorphic parameters calculated for the sub-catchments and channels subjected to analyses. Figure 3A identifies the channels; Figure 3B shows the ordered channels by the Strahler (1952) method and show a very uniform spatial distribution of the drainage channels in the catchment, suggesting a homogeneous lithology, except for the shear zone, where tectonics deformed highly complex primary structures. However, in a visual inspection, no significantly higher or lower drained area can be differentiated.

Three classes of drainage basin shape (Figure 3C) were observed (Table 4). High Bs ratio values indicate elongated basins, typical of high relief and steep slope areas; low Bs ratio values indicate more circular basins, common in areas of low relief and gentle slopes (SCHUMM, 1956; CANNON, 1976). The possibility of structural control is considered comparatively low in the Capivara catchment $(\mathrm{Bs}<2)$, which indicates a more circular drainage basin. Moderate values $(2.0 \leq \mathrm{Bs} \leq 3.5)$ were recorded in the cases of Cotovelo, Caiçara, Cana-brava, Mocambinho, and Trombas catchments. High values (Bs > 3.5) indicate elongated drainage basins, likely influenced by structural controls, were reported for Forquilha, Morro Redondo, Terra Vermelha, Alegre, Riachinho, and Tapioca creeks; perhaps these catchments may have been influenced by reactivated structures. It is important and representative that 6 out of 13 catchments seem to exhibit structurally controlled drainage incision and downcutting. Notably, only Terra Vermelha and Morro Redondo sub-catchments are entirely situated inside the Precambrian shear zone.

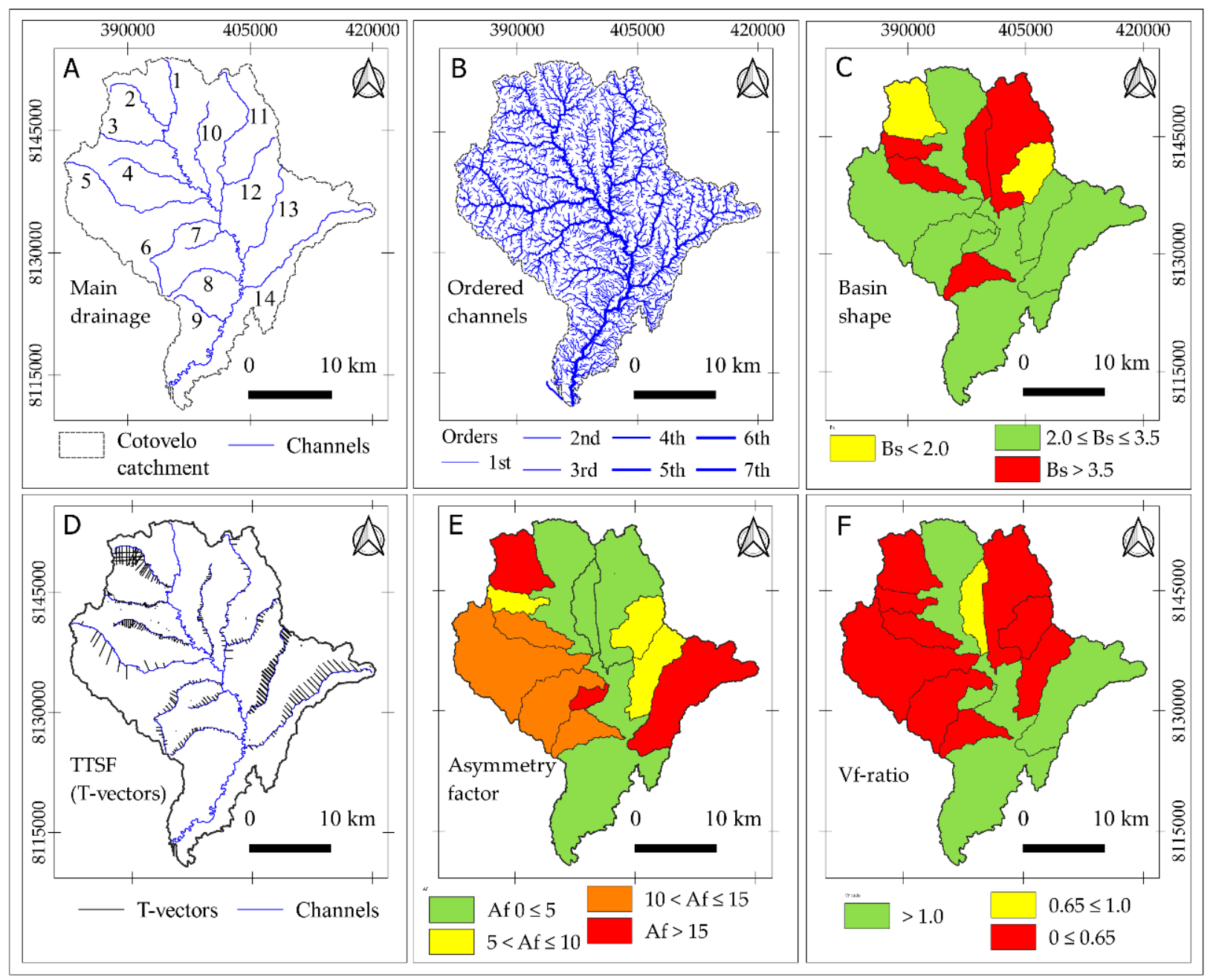

Figure 3: Geographic expressions of the Cotovelo River and their branches: A) Identified channels: 1) Cotovelo River, 2) Capivara Creek; 3) Tapioca Creek; 4) Alegre Creek; 5) Cana-brava Creek; 6) Mocambinho Creek; 7) Trombas Creek; 8) Riachinho Creek; 9) Morcego Creek; 10) Terra Vermelha Creek; 11) Morro Redondo Creek; 12) Caiçara Creek; 13) Assapeixe Creek; 14) Forquilha Creek. B) Automatically generated, ordered channels by the Strahler's (1952) method; C) Asymmetry factor index. D) Drainage basin shape index. E) Transverse topographic symmetry factor index; and F) valley floor width-to-height ratio. Red color highlights the sub-catchments with stronger evidence of structural control (passive and/or active). 
Table 4: Computed geomorphic indices for sub-catchments and their respective channels

\begin{tabular}{lcccccc}
\hline Catchments & Bs $^{(1)}$ & Af $^{(2)}$ & Vf-ratio $^{(3)}$ & T-vector $^{(4)}$ & SL-index $^{(5)}$ & River bank $^{\text {Cotovelo }}$ \\
\hline Assapeixe & 3.16 & 51.47 & 11.67 & 0.29 & 21,74 & - \\
Caiçara & 2.38 & 59.94 & 0.52 & 0.54 & 20,58 & Left \\
Forquilha & 3.99 & 70.57 & 1.25 & 0.13 & 19,85 & Left \\
Morro Redondo & 4.23 & 45.40 & 0.24 & 0.19 & 19,06 & Left \\
Terra Vermelha & 5.56 & 52.72 & 0.75 & 0.16 & 25,10 & Left \\
Alegre & 4.54 & 62.51 & 0.10 & 0.58 & 33,63 & Left \\
Cana-brava & 2.83 & 64.66 & 0.29 & 0.18 & 29,21 & Right \\
Capivara & 1.95 & 68.20 & 0.34 & 0.44 & 20,58 & Right \\
Mocambinho & 3.31 & 37.03 & 0.11 & 0.21 & 28,94 & Right \\
Riachinho & 4.52 & 39.79 & 0.07 & 0.18 & 30,97 & Right \\
Tapioca & 4.27 & 59.58 & 0.11 & 0.17 & 25,95 & Right \\
Trombas & 3.41 & 25.30 & 1.14 & 0.24 & 26,07 & Right \\
\hline
\end{tabular}

Note: ${ }^{(1)}$ Drainage basin shape (Bs), ${ }^{(2)}$ Asymmetry factor (Af), ${ }^{(3)}$ Valley floor width-to-height ratio (Vf-ratio), ${ }^{(4)}$ Transverse topographic symmetry factor (T-value), and ${ }^{(5)}$ Stream-length index (SL-index).

The results of the TTSF (T-vector) calculation showed internal differences among the sub-catchments and tributaries of the Cotovelo River, and at least three internal distinctive patterns were observed (Figure 3D). Values can be grouped into three classes, according to Sajadian et al. (2015): Class 1: $\mathrm{T}<0.2$ (low level of tilting); Class 2: $0.2 \leq \mathrm{T}<0.4$ (moderate level of tilting); and Class 3: $\mathrm{T} \geq 0.4$ (high level of tilting). The $\mathrm{T}$ vector values indicate low relative tectonic-based tilting (T-vector < 0.2) in sub-catchments of Caiçara, Morro Redondo, Terra Vermelha, Cana-brava, Riachinho, and Tapioca creeks. Moderate values of tectonicbased slant $(0.2 \leq \mathrm{T}$-vector $<0.4)$ were found in the Forquilha, Mocambinho, and Trombas sub-catchments. Finally, higher relative tectonic-based tilting (T-vector $\geq 0.4$ ) was characteristic of the Assapeixe, Alegre, and Capivara catchments. Apparently, this dip seems to be a randomic response to structural weakness lines. However, they are interpreted as resulting from an uplifted block observed along a line crossing the left divides of Mocambinho and Morro Redondo sub-catchments. Furthermore, the northern tributaries Capivara, Alegre, and Cana-brava creeks migrate toward N-NE, which seems to be caused by the adjustment of Precambrian weakness lines. The southern branches Mocambinho, Trombas, Riachinho, Assapeixe, and Forquilha drifted their channels toward the southeast, indicating control in the SW-NE direction. Finally, the Tapioca, Terra Vermelha, Morro Redondo, and Caiçara creeks have channels fitted to the shear zone structural directions. Assessed Southeastern and Southern Brazilian rivers provided analogous index outputs, showing lateral migration of river channels due to block tilting (CAMOLEZI et al., 2012; PAES; SILVA, 2017).

The asymmetry factor (Af) absolute values ranged from 25.3 to 70.5 (Figure 3E) in this study (Table 4). Reference values for Af are (SALVANY, 2004; PÉREZ-PEÑA et al., 2010): Af < 5 (symmetric catchments); $5 \leq$ Af $<10$ (gently asymmetric catchments); $10 \leq$ Af $\leq 15$ (moderately asymmetric catchments); Af > 15 (strongly asymmetric catchment). Cotovelo, Terra Vermelha, and Morro Redondo were categorized as symmetric catchments, indicated by lower Af values $(<5.0)$. These three streams flow predominantly in the north-south direction, fitted to the Precambrian NNW-SSE shear zone structures; the Terra Vermelha and Morro Redondo creeks are tributaries of the left bank of the Cotovelo River.

Caiçara, Tapioca, and Assapeixe were classified as gently asymmetric catchments $(5 \leq \mathrm{Af}<10)$. However, a distinction must be made: Caiçara and Assapeixe creeks are tributaries of the left bank of the Cotovelo River and have springs in the Morro Redondo Plateau, flowing toward the southwest. Tapioca creek springs at the Boqueirão Plateau, on the right bank, and flows toward the east-southeast.

Alegre, Cana-brava, Mocambinho, and Riachinho creeks were labeled as moderately asymmetric catchments, suggestive of tilting blocks $(10<\mathrm{Af} \leq 15)$. All sub-basins are tributaries from the right bank of Cotovelo. The Cana-brava and Alegre streams have displaced their course to the left margin toward the NNE. Mocambinho and Riachinho moved toward the S-SE to their right margins. In the former cases, a Precambrian structural setting can be responsible for the lateral migration of the channels.

Finally, Capivara, Forquilha, and Trombas belong to the strongly asymmetric catchment typology (Af > 15), a powerful indication that their channels flow over tilted blocks. On one hand, the more impressive shift of the Capivara channel toward N-NE indicates an adjustment to the NNW shear zone structures. Being higher energy channels, Capivara and Forquilha creeks do not developed alluvial plains. Differently, outside the shear zone, Forquilha and Trombas channels shifting to the southeast direction may be interpreted as strong evidences of differential and singular adjustment, as well as reinforce the possible existence of a 
tilting block toward the southeast; the slant induces preferential erosion in the right margin of the Capivara, Assapeixe, and Forquilha catchments. Trombas, Riachinho, and Assapeixe creeks (and Morcego, a very small, not assessed creek), lower Af values catchments, spread their loads over the Cotovelo river floodplain, in a way of parallel, overlapped alluvial fans. Presently, these fans are subjected to accelerated incision due to a recent fall in the local base-level; this lowering arrived at the Cana-brava and Alegre outlets.

Values of valley floor width-to-height ratio (Vf-ratio) were used to assess the existence of some possible recent tectonic reactivation of Precambrian and/or probable more recent structures and its manifestation in the Cotovelo River catchment and their sub-catchments (Figure 3F); the ratios ranged between 0.07 and 1.25 (Table 4). High values of Vf (Vf-ratio > 1.0) indicate broad-floored canyons U-shaped valleys; low values of Vf (Vf-ratio $\leq 1.0)$ indicate dissected V-shaped valleys (BULL; MCFADDEN, 1977; EL HAMDOUNI et al., 2008). Riachinho, Alegre, Mocambinho, Tapioca, Caiçara, Morro Redondo, Cana-brava, Capivara, and Assapeixe creeks displayed the lowest values of this index (between 0.07 and 0.52); these channels fall into Class 1 (tectonically active fronts) of Pérez-Peña et al. (2010), that is, streams in high-energy condition, positioned at eastern front of the Boqueirão scarp and western border of the Morro Redondo Plateau. Progressively higher Vf-ratio values provide indicative evidence that local streams actively downcut their beds (SILVA et al., 2003; PEDRERA et al., 2009), influenced by a base-level fall (NTOKOS et al., 2016), which can be correlated with the Boqueirão scarp retreat. The Terra Vermelha creek displays a comparatively high Vf-ratio value (0.75), which explains a slight downcutting, perhaps resulting from the subsidence of the Cotovelo low-valley sedimentary plain. The Trombas and Forquilha creeks present the largest Vf-ratio values (1.14 and 1.25, respectively) among the different sub-basins and are set in inactive fronts (SILVA et al., 2003).

There is a clear correlation between the Vf-ratio values and linear structures in the study area; lower values arose near eastern scarps of the Boqueirão Plateau and Western scarps of the Morro Redondo Plateau, and these values increased away from the structures. Therefore, elevated Vf-ratio values are located on the hanging wall of the Boqueirão and Morro Redondo fault lines (CPRM, 2003a; 2003b), and lower values occurred within the sedimentary basin, noticeable in the pediments and debris flow fanglomerate surfaces. Applied to the Brazilian Northeast onshore region, the index yielded similar results, identifying present tectonic control on landforms (BARBOSA et al., 2013; BARBOSA; FURRIER, 2017), and these values are closer to the ones achieved nearby the Hellenic Arc (NTOKOS et al., 2016).

Additionally, eight specific fronts/scarps (Figure 4) were assessed using the mountain front sinuosity index (BULL; MCFADDEN, 1977), and isolated channels crossing the fronts were checked by the valley floor width-to-height ratio (Vf-ratio) index. Table 5 lists the outcomes. Reference values (RAMÍREZHERRERA, 1998; PÉREZ-PEÑA et al., 2003; SILVA et al., 2003) for the index are: Smf < 1.4 (probable tectonic activity); $1.4 \leq \mathrm{Smf} \leq 3.0$ (probably low or undefined tectonic activity); and Smf $>3.0$ (totally inactive fronts).

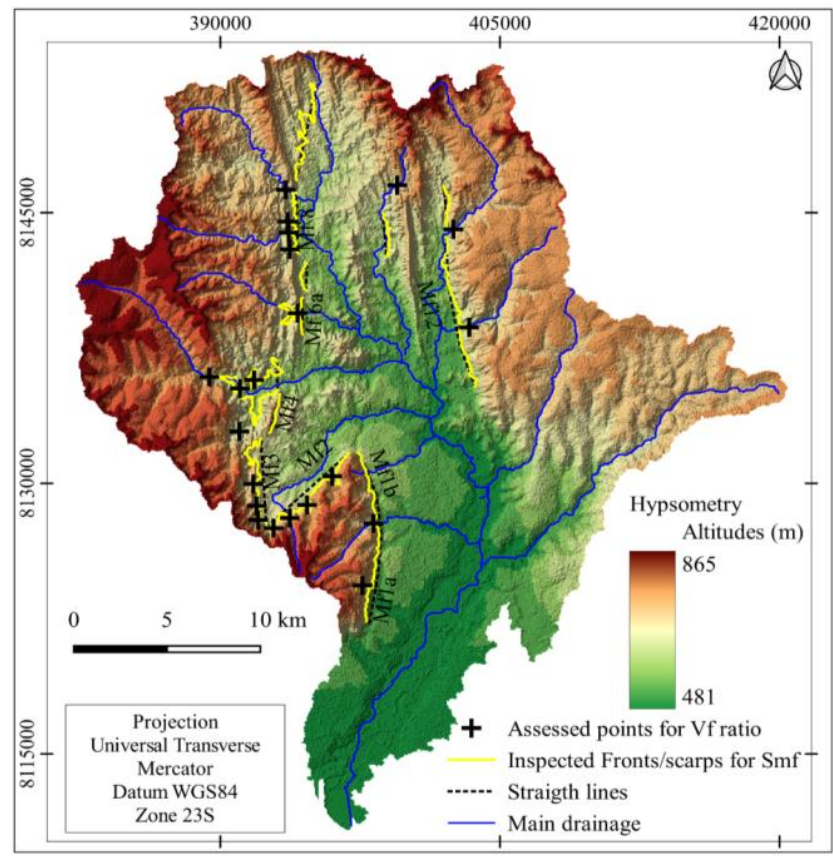

Figure 4: Hypsometry map of the Cotovelo catchment with scarps/fronts assessed using Smf index and isolated channels assessed by the Vf-ratio 
Table 5: Mountain front sinuosity and valley floor width-to-height ratio for eight selected fronts/scarps

\begin{tabular}{cccccc}
\hline \multirow{2}{*}{ Fronts/scarps } & \multirow{2}{*}{ Assessed channels } & \multirow{2}{*}{ Smf } & \multicolumn{3}{c}{ Vf-ratio } \\
\cline { 5 - 7 } & Morcego creek & 1.88 & 14 & 1.87 & 1.56 \\
Lmf-1a & Trombas creek & 1.33 & 23 & 0.47 & 0.60 \\
Lmf-1b & Mocambinho creek - tributary & 1.51 & 27 & 0.89 & 0.76 \\
Lmf-2 & Mocambinho creek & 2.03 & 10 & 0.30 & 0.46 \\
Lmf-3 & Cana-brava creek & 10.96 & 17 & 0.06 & 0.15 \\
Lmf-4 & Alegre creek & 2.55 & 9 & 0.12 & 0.20 \\
Lmf-6a & Tapioca creek & 1.91 & 19 & 0.03 & 0.10 \\
Lmf-8 & Caiçara creek & 1.33 & 9 & 0.01 & 0.06 \\
Lmf-12 & &
\end{tabular}

Note: ${ }^{(1)} n$ is the number of stream valleys assessed for $V f$-ratio calculation. ${ }^{(2)} \sigma$ is the standard deviation of the Vf-ratio calculation.

On assessing the Vf-ratio for selected mountain fronts, the results showed that seven fronts yielded clustered average values of Vf-ratio $<1.0$, which indicates an aggressive linear incision of the riverbed and suggests the probability of a recent front uplift (PEDRERA et al., 2009). Only one front produces a higher mean value (Vf-ratio > 1.56), which points to dominant lateral erosion and low riverbed dissection and conveys no recent uplift (KELLER; PINTER, 2002).

Seven fronts/scarps (Table 5) yielded a broad Smf range from 0.99 to 2.55, and one abnormal result (10.96). Because the lithology is very uniform in the area, variability is probably due to structural passive and active control of the faulted and folded terrain of the NNW-SSE Precambrian shear zone and the existence of a Precambrian inverse fault in the piedmont of the Morro Redondo and Três Irmãos Plateaus (CPRM, 2003a; 2003b).

In agreement with the reference values proposed by Ramírez-Herrera (1998), Pérez-Peña et al. (2010), and Silva et al. (2003), two fronts (Lmflb in the right margin and the Lmf-12 in the left margin) present Smf values below 1.4 threshold, and are interpreted as "more likely to record a recent uplifting". The other five fronts (Lmf-1a, Lmf-2, Lmf-3, Lmf-6a, and Lmf-8, all at the right margin) yielded intermediate Smf values, between 1.4 and 3.0, indicating "a medium or undefined probability of a recent uplifting." Lastly, the front Lmf-4 (Cana-brava Creek) yielded a Smf value of 10.96, an abnormal result, is explained by the sub-basin topographic settings of the Cana-brava Creek catchment; although it crosses the front in a relatively deep and narrow canyon, the Cana-brava headward aggressive erosion creates a broad drainage area.

Regarding the SL-index, generally, low values correlate to less steeper channels and have been used to describe low-rate or tectonically inactive areas, as well as rivers flowing over less erosion-resistant bedrocks (HACK, 1973; VIVEEN et al., 2012). High SL-index values are usually suggestive of tectonically active areas (KELLER; PINTER, 1999), erosion-resistant bedrock, or headward migrating knickpoints (BURBANK; ANDERSON, 2001; VIVEEN et al., 2012). In doing so, the resulting values were rated in three classes $\mathrm{SL} / \mathrm{K}<2.0$ (no anomalous stream), $2.0 \leq \mathrm{SL} / \mathrm{K}<10.0\left(2^{\text {nd }}\right.$ order anomaly), and $\mathrm{SL} / \mathrm{K} \geq 10\left(1^{\text {st }}\right.$ order anomaly), as proposed by Seeber and Gornitz (1983), dividing the SL-value of a reach (SL) for the SLvalue of the entire channel $(\mathrm{K})$, and the values were plotted against the longitudinal and the geologic river profiles. From the first outcome resulted the significance of predominant intermediate values $(2 \leq \mathrm{SL} / \mathrm{K}<$ 10 ), which fall into the $2^{\text {nd }}$ order anomaly. These plots were visually inspected in the DEM, slope map, satellite image, and using field-based experience (Figure 5), looking for coexisting knickpoints and filled-up areas, different rock type transitions, mapped and inferred faults, and lineaments.

The SL-index value computed for the whole Cotovelo River channel was 22.25, pointing to an ungraded river, because it supposes the necessity of adjusting the longitudinal profile to the bed (Figure 6). The $2^{\text {nd }}$ order anomalies present in the middle valley suggest a rock-resistant bed as well as lithological transitions and diversity inside the NNW-SSE shear zone (CPRM, 2003a; 2003b), acting to the increasing or decreasing stream velocity. These values increase progressively toward the outlet, probably as a consequence of the tributaries' bedload and discharge supply. Entering its low-valley sedimentary floodplain, the river changes the dynamics substantially because of the amount of sediment, while yielding $1^{\text {st }}$ order anomalies; another possible reason for these anomalies is the interference for the highway (MG-667 connecting the cities of Brasilândia de Minas and Santa Fé de Minas) filling of the profile, and increasing the road grade; this obstruction may have caused deep impacts in the fluvial dynamics. 

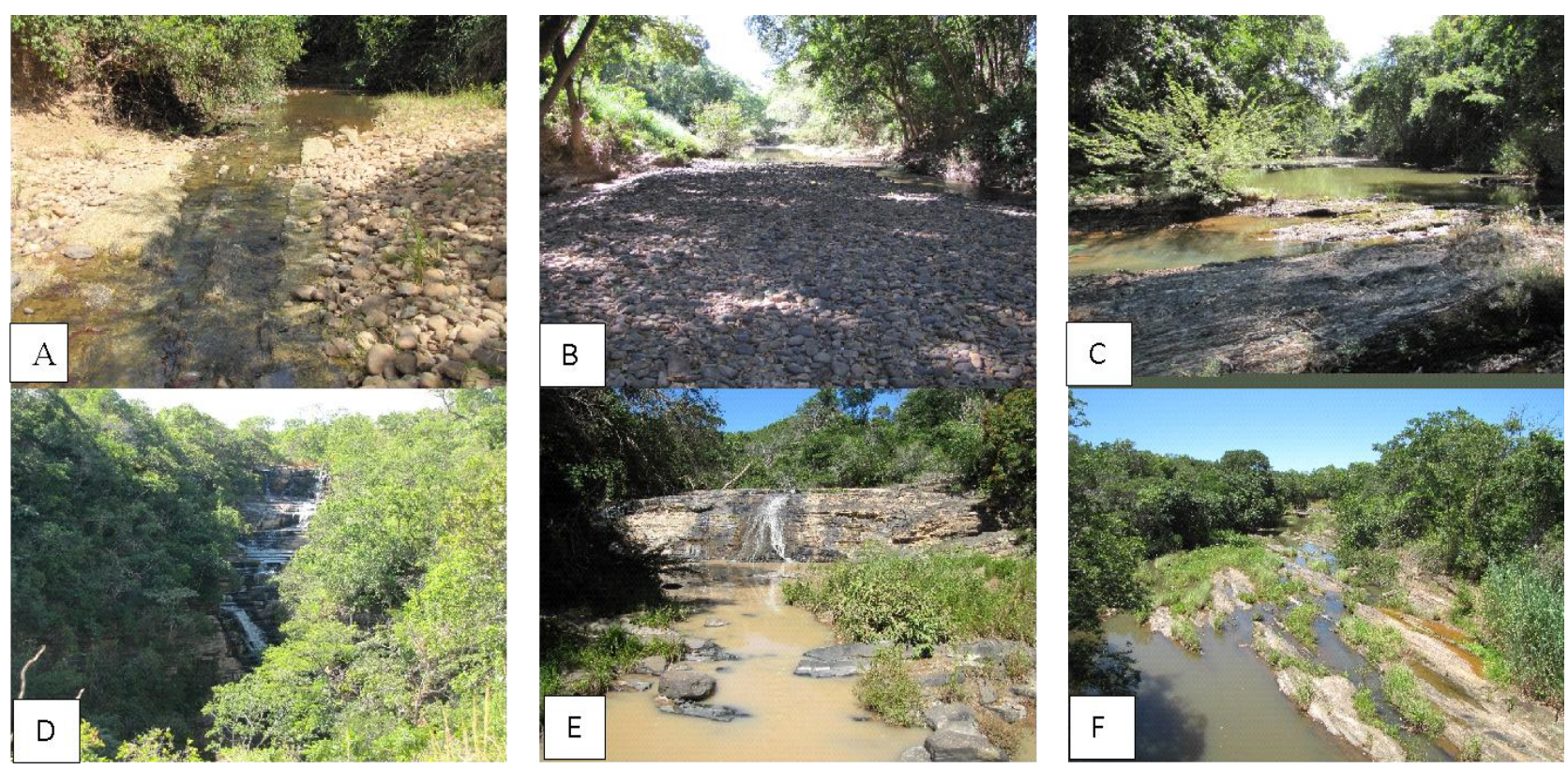

Figure 5: Knickpoints and knickzones along the river channels, in the Cotovelo catchment: A) Knickpoint in the Assapeixe channel, near the outlet (the river crosses the bedrock along the structure); B) Cotovelo riverbed during the dry season (the riverbed is paved with cobbles and pebbles); C) Knickpoints along the Cotovelo riverbed (the river crosses the rock structure diagonally); D) Fall in the Alegre creek (the knickpoint has around a height of $30 \mathrm{~m}$ ); E) Knickpoint in the Capivara creek channel; F) Knickzone along the Morro Redondo creek channel.

\section{Cotovelo river}

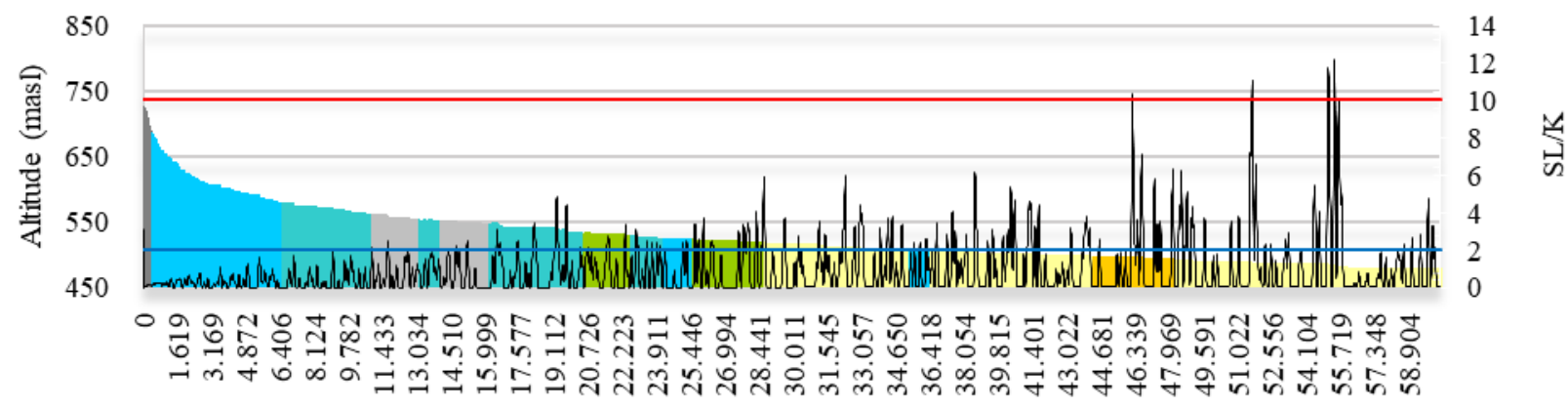

Distance from headwater (m)

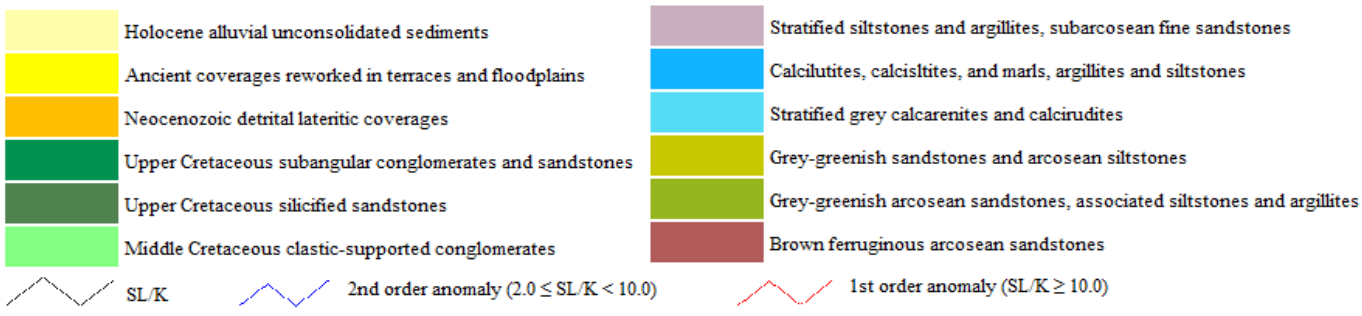

Figure 6: Longitudinal profile of the Cotovelo River, and reaches of steep $(2.0 \leq \mathrm{SL} / \mathrm{K}<10.0)$ and very steep $(\mathrm{SL} / \mathrm{K} \geq 10.0)$ gradients. Legend refers to all subsequent longitudinal profiles.

In the right bank (Figure 7), Capivara Creek presents a regular straight-to-convex upward profile, with no impressive knickpoint perceived in the curve. Anomalies of $2^{\text {nd }}$ order were computed in different pelitic and carbonated bedrock of the Santa Helena and Lagoa do Jacaré formations in the low valley. Therefore, Capivara Creek can be considered to have a non-disturbed graded profile. The other river profiles in the right margin (Tapioca, Alegre, Cana-brava, Mocambinho, Trombas, and Riachinho creeks) have at least one remarkable knickpoint, with more than $150 \mathrm{~m}$, coexisting with $2^{\text {nd }}$ order (Alegre, Mocambinho, Trombas, and Riachinho) or $1^{\text {st }}$ order (Tapioca and Cana-brava creeks) anomalies. These $1^{\text {st }}$ order anomalies occur predominantly at the borders of the arkosean sandstones at higher topographic breaks. The $2^{\text {nd }}$ order 
anomalies coincide with siltstones and argillites of the Serra da Saudade Formation, and this break places an upstream straight-to-convex upward segment profile and a downstream concave-segment profile. Another striking feature is the hanging valleys in all these channels upstream of the knickpoints, except for the Capivara creek. These hanging positions at the eastern border of the Boqueirão Plateau can be associated with a normal fault mapped in the scarp (CPRM, 2003a; 2003b).

The Tapioca and Cana-brava creeks show remarkable $1^{\text {st }}$ order anomalies bordering impressive scarps, suggesting the existence of a fault line. A similar feature corresponds to a $2^{\text {nd }}$ order anomaly that exists in the Alegre, Mocambinho, and Riachinho creek profiles. All these anomalies fit the direction of a mapped fault line (CPRM, 2003a; 2003b). The Trombas creek profile yielded no SL-index anomalies, although the course springs at the plateau with an impressive scarp.

Capivara creek

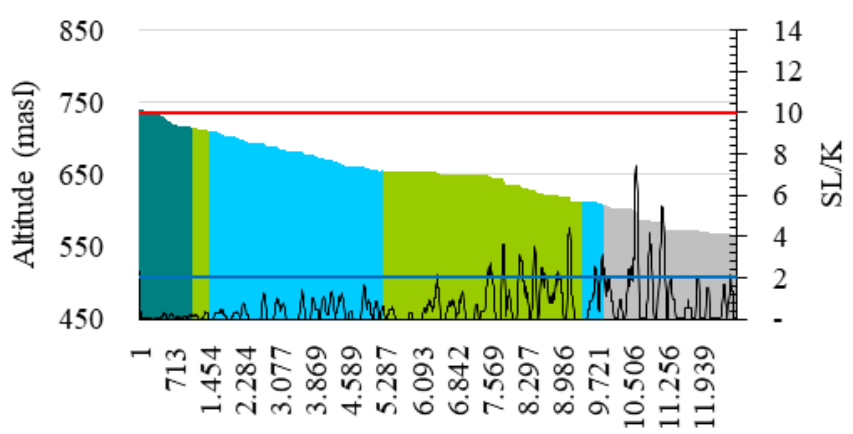

Distance from headwater (m)

Alegre creek

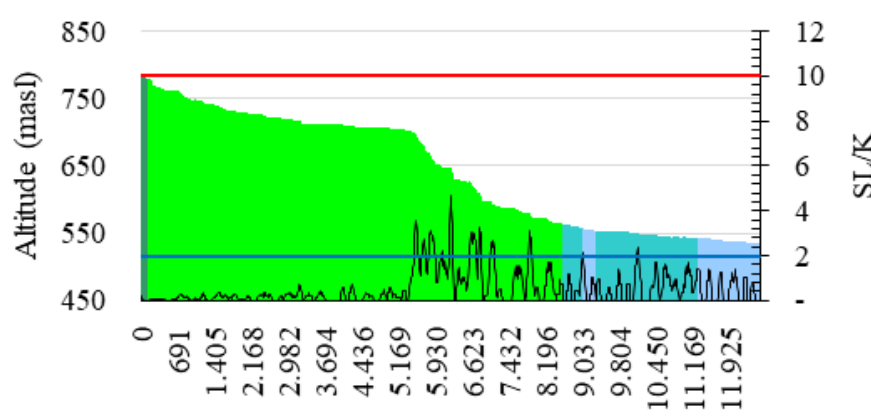

Distance from headwater (m)
Tapioca creek

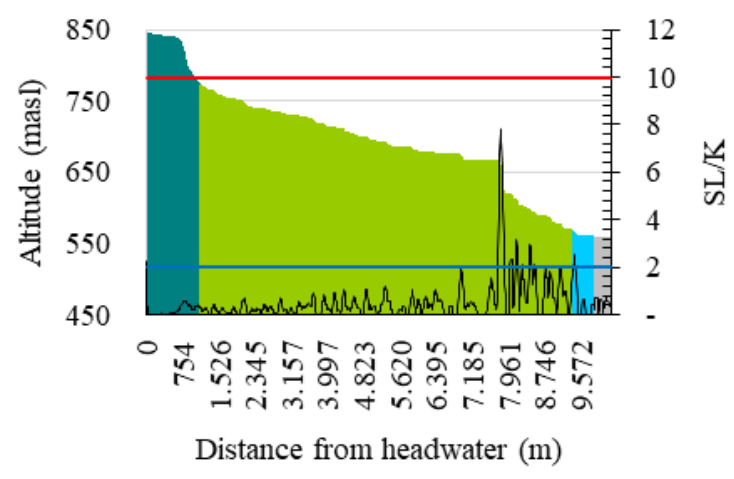

Trombas creek

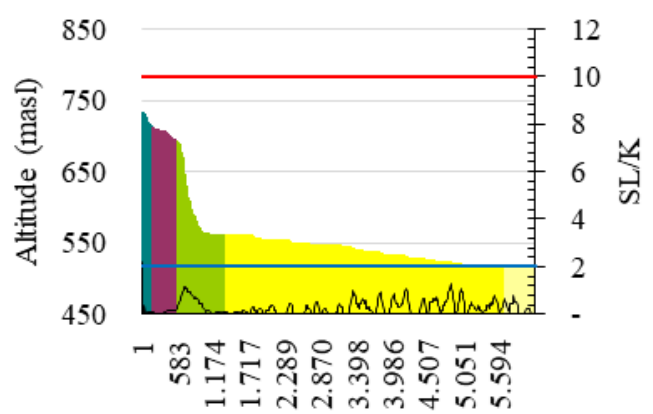

Distance from headwater (m)

Cana-brava creek

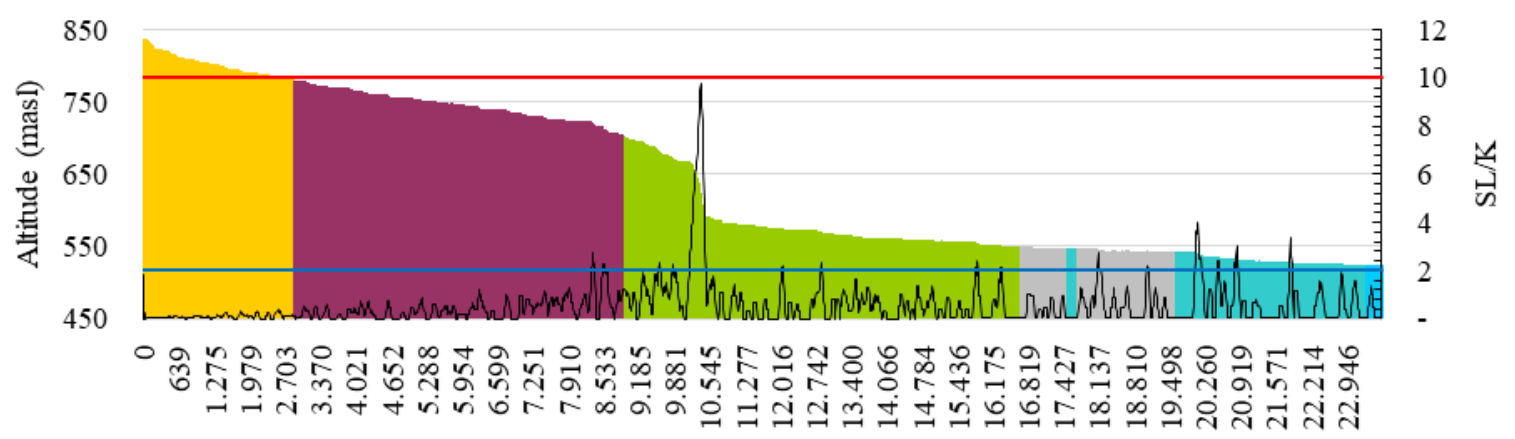

Distance from headwater (m) 
Mocambinho creek

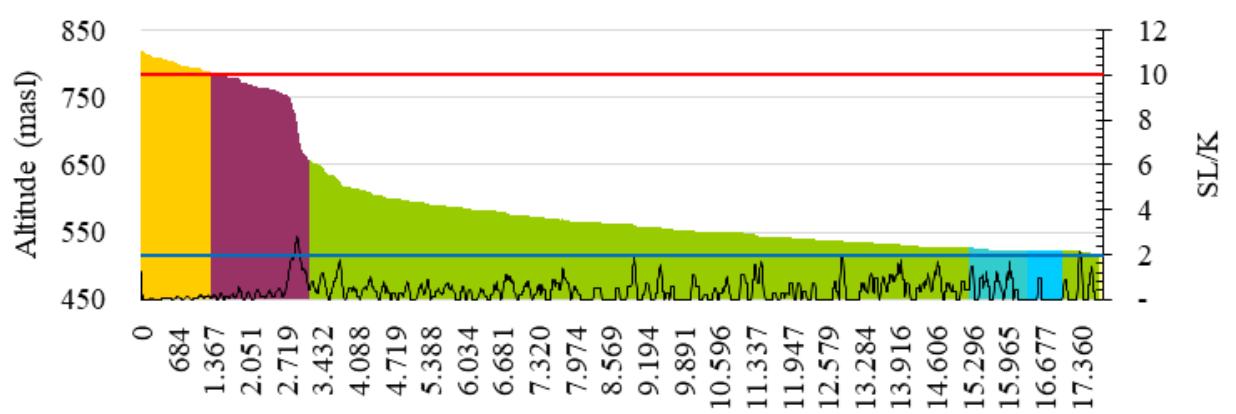

Distrance from headwater $(\mathrm{m})$

Riachinho creek

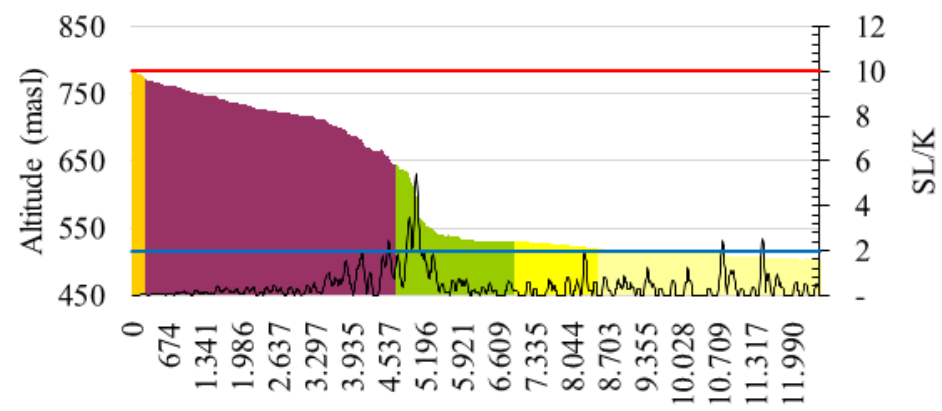

Distance from headwater

Figure 7: Longitudinal profile of the Capivara, Tapioca, Alegre, Cana-brava, Mocambinho, Riachinho, and Trombas creeks, and reaches of steep $(2.0 \leq \mathrm{SL} / \mathrm{K}<10.0)$ and very steep $(\mathrm{SL} / \mathrm{K} \geq 10.0)$ gradients.

In the left bank (Figure 8), the Terra Vermelha creek has a concave-upward profile, with small knickpoints associated with the predominant pelitic and carbonated bedrock of the Serra da Saudade and Lagoa do Jacaré formations. The Morro Redondo creek has three impressive knickpoints. The first, situated near the headwater, at $100 \mathrm{~m}$, dissects Upper Cretaceous sandstones of the Três Barras Formation; the others, situated in the middle valley, have two main steps, $60 \mathrm{~m}$ each one, resulting from the incision over the arkosean sandstones, siltstones, and argillites from the Serra da Saudade Formation. The Assapeixe and Forquilha creeks have convex upward profiles with extensive knickzones because their channels fit to fresh arkosean sandstones of the Três Marias Formation. Numerous $2^{\text {nd }}$ order anomalies result from the steepest segments of the continuous knickzones. The Caiçara Creek has an almost straight longitudinal profile, fitted to arkosean sandstones, siltstones, and argillites of the Serra da Saudade Formation. The $2^{\text {nd }}$ order anomalies correspond to folded and fractured siltstones and argillites of the Lagoa do Jacaré Formation. The Terra Vermelha and Caiçara creeks can be considered non-disturbed because their profiles resemble graded rivers. In the profiles of the left bank tributaries, hanging valleys are observed only in the Morro Redondo creek, emplaced by a knickpoint associated with the fold-and-thrust terrain of the NNW-SSE shear zone.

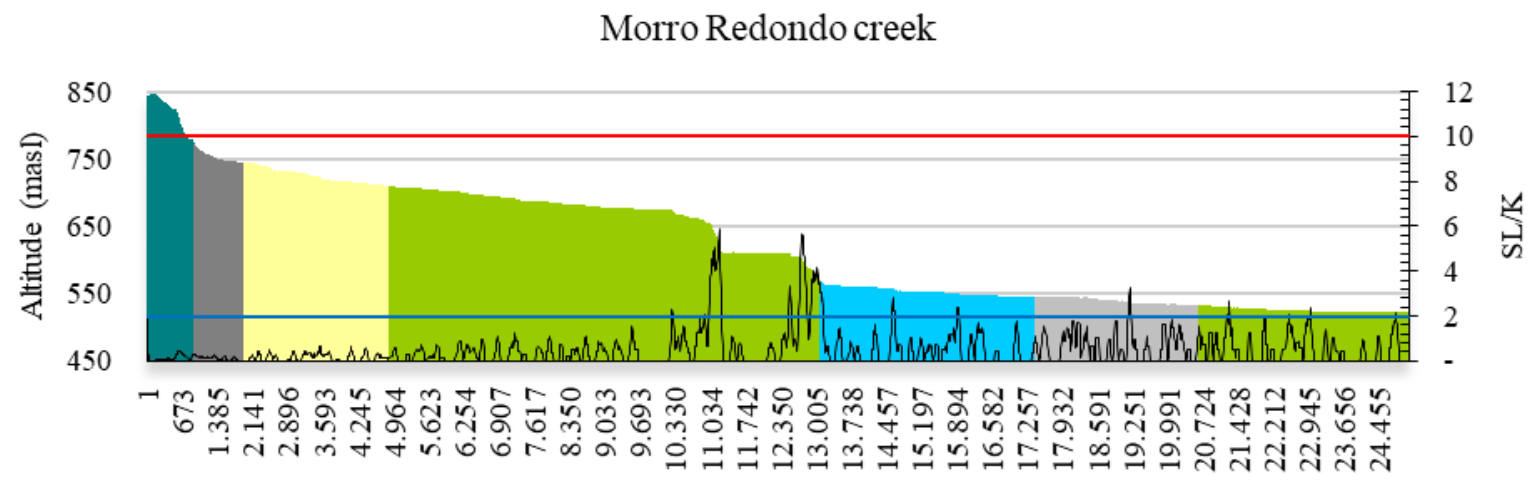

Distance from headwater (m) 
Terra Vermelha creek

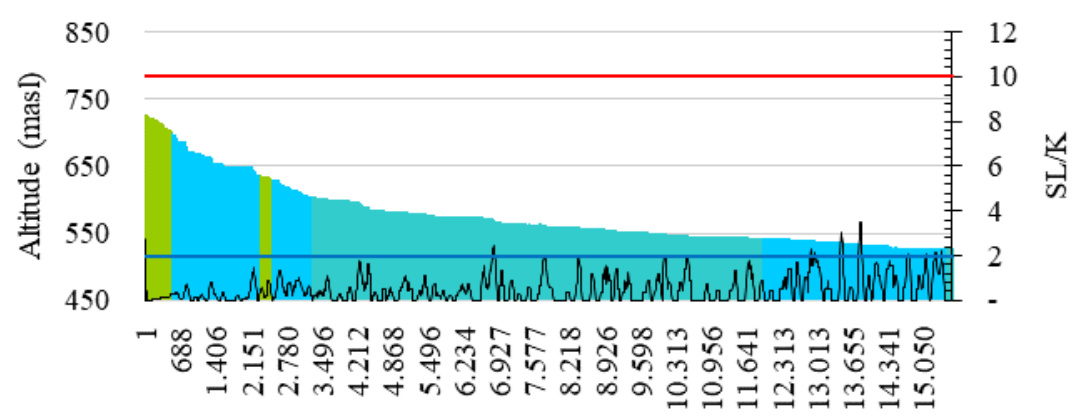

Distance from headwater $(\mathrm{m})$

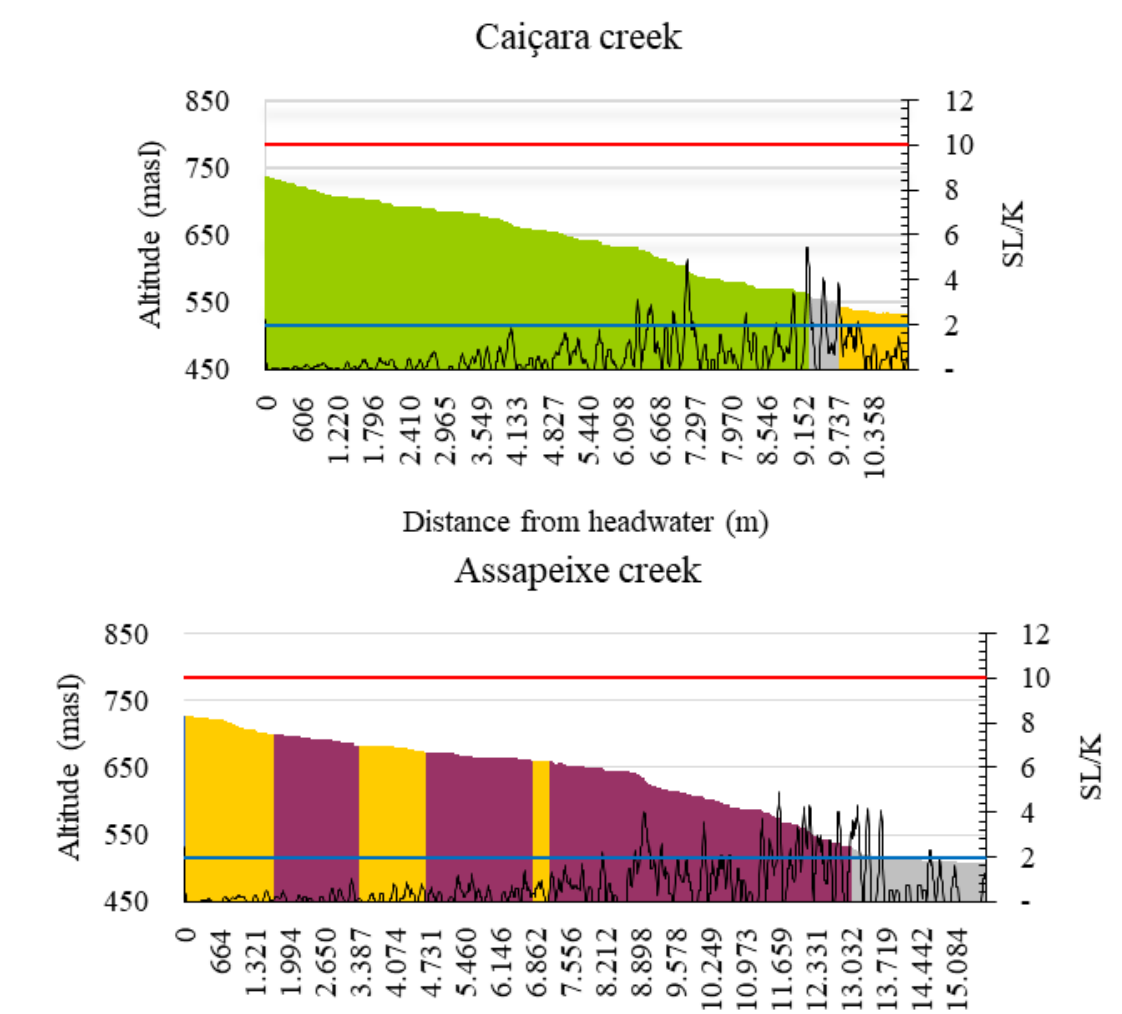

Distance from headwater $(\mathrm{m})$

Forquilha creek

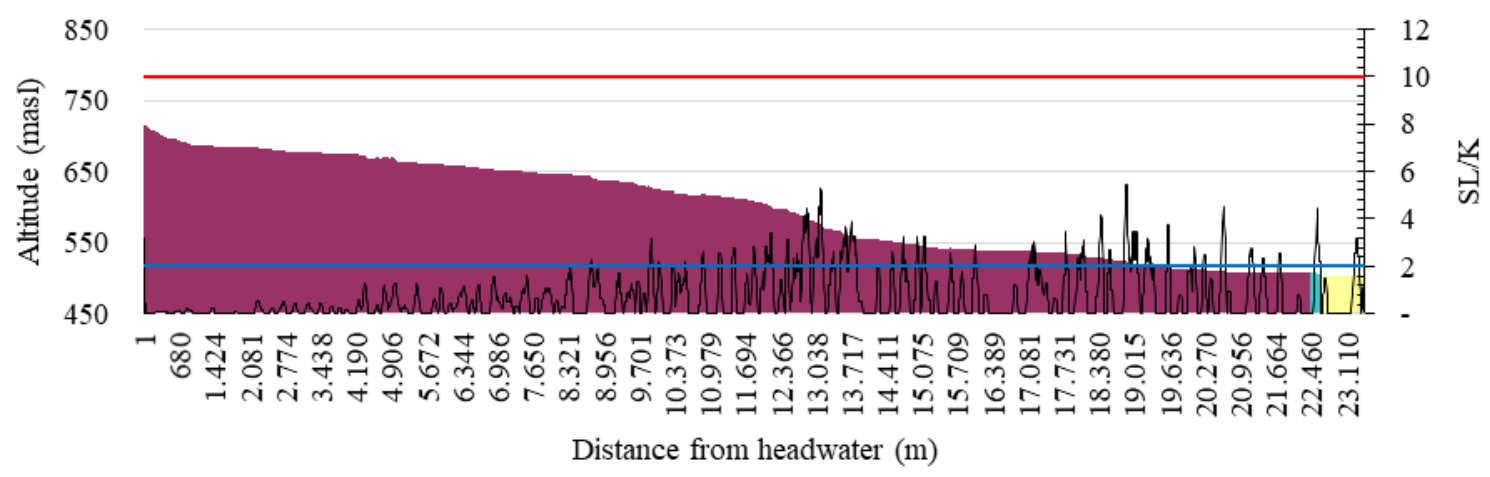

Figure 8: Longitudinal profile of the Terra Vermelha, Morro Redondo, Caiçara, Assapeixe, and Forquilha creeks, and reaches of steep $(2.0 \leq \mathrm{SL} / \mathrm{K}<10.0)$ and very steep $(\mathrm{SL} / \mathrm{K} \geq 10.0)$ gradients.

Suggestive of relative tectonic activity (EL HAMDOUNI et al., 2008), at the southern boundary of Southern Amazonian Craton, and inside the Paraíba and Araripe sedimentary basins, SL/K > 6 support lowrate neotectonic reactivation report (ANDRADES FILHO; ROSSETTI, 2015; OLIVEIRA et al., 2018; ALMEIDA et al., 2020). 
In summary, the tributaries of the Cotovelo River share analogous underlying rock strata and geomorphic and geometric characteristics. In the right bank, all the channels have one prominent knickpoint aligned with a mapped fault scarp. Other smaller knickpoints are close to different fractures and inferred lineaments and disclose preferential erosive fronts. Although no one active fault was mapped in the area, the presence of straight segments in the profiles - even the bordering lineaments - can be interpreted as indicative of differential uplift or subsidence taking place in the Cotovelo catchment. Notwithstanding the regional scale of the geologic map, a knickpoint was considered to be derived from a fault or a fracture when it coincided with a lineament on the DEM and did not correspond to a stratigraphic border in the geologic map. Therefore, the knickpoints mapped in the Cotovelo catchment were not related to lithological changes. Channels in the Cotovelo catchment share similar geomorphodynamic conditions, expressed in the headward incision, through the base-level controlled tectonic subsidence of the low river valley.

Essentially, the Brazilian intraplate geomorphic landscape is strongly shaped by the reactivation of weakness zones and Precambrian faults and fractures, a process controlled by the Gondwana break-up and the opening of the Atlantic Ocean, since the Mesozoic that led the South America Plate rotation and drifts toward the West (HASUI, 1990; SAADI, 1991; 1995). Through this process, fluvial and landform dynamics are broadly driven by Proterozoic or older rocks and structures (PINTO et al., 2018). Moreover, straight, parallel, and oriented drainage, asymmetrical catchments, tilted blocks, drifted channels, among others, provide strong evidences of persistent low-rate tectonic processes conditioning the development of small landforms and continuous adjustment of river patterns (MAGALHÃES Jr; SAADI, 1994; FULFARO et al., 2005; ETCHEBEHERE et al., 2006; MENDES et al., 2007; BARROS et al., 2010a; 2010b; GONTIJOPASCUTTI et al., 2010; MARQUES NETO; PEREZ FILHO, 2013; 2014; CHEREM et al., 2018).

In the case of the Cotovelo catchment, relatively elongated and asymmetric catchments seem to be consequence of block tilting, due to shear zone structural configuration and maybe the recent tectonic reactivation of Brasiliano structures (SAADI, 1991; HIRUMA; PONÇANO, 1994). Because catchments of both margins were assessed, asymmetry of drainage was examined in terms of absolute values. Indeed, $\mathrm{T}$ vector and Af data evoke the existence of two morphotectonic units inside the Cotovelo catchment, delimited by a SW-NE line, crossing the left-bank divides of Mocambinho and Morro Redondo creeks. Actually, from this line, channels shift toward its both flanks, which points out to the possible existence of an uplifted block; analogous features were described in Brazilian intracratonic (SANTOS; CASTRO, 2016; SANTOS; MORAIS, 2017) and passive margin terranes (ALVES; ROSSETTI, 2017; PEYERL et al., 2018), and morphotectonic settings were explained by neotectonics.

Furthermore, significant results of Vf-ratio, Smf, and Sl-index in the Boquerão Plateau high-energy drainage systems, associated to migration of river channels induced by tectonic tilting also reinforce the hypothesis of neotectonic activity, as previously shown elsewhere in the Brazilian Shield (SALAMUNI et al., 2004; BARROS et al., 2010a; 2010b; SANTOS et al., 2015; LAVARINI et al., 2016; ALMEIDA et al., 2020).

\section{Conclusion}

There is solid evidence of structural influence on the Cotovelo River drainage arrangement in the northwestern Minas Gerais State, as impressive shifting of fluvial channels and relevant quantitative values of geomorphic indices that are indicative of asymmetries and block tilting. Though any isolated analysis is still not sufficient to confirm that tectonic control is active, the integrated assessment of geomorphometric indices reveal that this river catchment is a prominent and conspicuous part of the geomorphological landscape that, even inserted in a cratonic environment, have some of their short tributaries (Assapeixe and Caiçara) viewed as younger, vigorous, and lesser-eroded catchments. In contrast, the larger and longer alluvial tributary rivers (Morro Redondo, Terra Vermelha, and Riachinho) are sedimentary-prone catchments. Local bedrock rivers (Capivara, Tapioca, Alegre, Cana-brava, and Forquilha) exhibit more dissected catchments because their courses flow over resistant lithology. The predominance of impervious subsurface, undulated or hilly landscapes, and highly dissected and denser drainage networks correlate to characteristics of sedimentary and metasedimentary regional basement. Adjacent to the Boqueirão scarps, geomorphometric indices reveal elongated drainage basins, characterized by medium to high relief and steep slope, along with geological heterogeneity and higher permeability resulting from fractures, which remarkably indicate structurally drive fluvial dissection.

Despite the lack of detailed topographic, geologic and geomorphologic information, given the scales of available maps, geomorphic description as well as the geomorphic indices computed largely suggest tectonic and structural control on the drainage network, longitudinal river profiles, drainage basin shapes, and 
landforms. From one hand, Forquilha and Assapeixe creeks exhibit the clearer structural control, derived from the Cenozoic tectonic event; on the other hand, Tapioca, Alegre, Mocambinho, Trombas, and Riachinho creeks incised their valleys into weaker zones crossing the Boqueirão Plateau. The upper segment of the Cotovelo, the Morro Redondo, and Terra Vermelha catchments are perfectly adjusted to the Precambrian shear zone; in these cases, they are very elongated drainage basins. In the right bank, high energy tributaries drain the Boqueirão plateau dissecting deep and narrow gorges, resulting in impressive knickpoints. In both margins, the parallelism of the channels reinforces the hypothesis of structural control, which is supported by the low average values of the T-vectors, indicating that channel displacement was relatively short.

However, in the absence of any mapped and described active faults, there is still not sufficient evidence to definitively attest the neotectonic activity in the area. Thus, the processes responsible for morphogenetic evolution of the catchment may be ascribed primarily to lithologic and structural patterns, possibly, under blind fault control.

\section{Acknowledgements}

This study was partially supported by the National Council for Scientific and Technological Development (CNPq) grants (PROAP, through the Student Financial Assistance Service of the Postgraduate Program in Physical Geography/FFLCH/USP, and CNPq financial support through Process n 409944/20165). Thanks to the Editor, to the reviewers and to Professor Ricardo Diniz da Costa for valuable comments, suggestions and writing improvements.

\section{References}

ACKLAS JR, R.; ETCHEBEHERE, M.L.; CASADO, F. C. Análise de perfis longitudinais de drenagem no município de Guarulhos para detecção de deformações neotectônicas. Revista Universidade de Guarulhos - Geociências, v. VIII, n. 6, p. 64-78, 2003.

ALKMIM, F.; MARSHAK, S. Transamazonian Orogeny in the Southern São Francisco Craton Region, Minas Gerais, Brazil: evidence for Paleoproterozoic collision and collapse in the Quadrilátero Ferrífero. $\begin{array}{lllllll}\text { Precambrian Research, } & \text { v. } 90, \quad \text { n. } & 1-2, & \text { p. } & 29-58, & 1998 .\end{array}$ http://linkinghub.elsevier.com/retrieve/pii/S0301926898000321.

ALMEIDA, A.T.S.; FELIPE, L.B.; MASCARENHAS, A.L.S.; SILVA JR, O.G. Caracterização morfométrica e neotectônica da bacia hidrográfica do Rio Vermelho - Sudeste do Pará. Geociências, v. 39, n. 4, p. 977-995, 2020. https://doi.org/10.5016/geociencias.v39i04.15331

ALVES, F.C.; ROSSETTI, D.F.; ANDRADES FILHO, C.O.; CREMON, E.H. Fator de Assimetria e deformações tectônicas na Bacia Paraíba, Nordeste do Brasil. Revista Geonorte, v. 10, p. 128-134, 2014.

ALVES, F.C.; ROSSETTI, D.F. Neotectonic record in South American passive margin based on morphostructural analysis of northern Paraíba Basin, Brazil. Zeitschrift für Geomorphologie, v. 61/2, 95108, 2017. https://doi.org/10.1127/zfg/2017/0383

ANDRADES FILHO, C.O.; ROSSETTI, D.F. Intensidade da atividade tectônica na porção emersa da Bacia Paraíba e embasamento cristalino adjacente, Nordeste do Brasil. Pesquisas em Geociências, v. 42, n. 2, p. 113-130, 2015.

ASF-DAAC. ALOS PALSAR Radiometric Terrain Corrected high resolution 2015; Includes Material (C) JAXA/METI 2007. Accessed through ASF-DAAC 06 June 2018. https://doi.org/10.5067/JBYK3J6HFSVF

AZOR, A.; KELLER, E.A.; YEATS, R.S. Geomorphic Indicators of Active Fold Growth: South MountainOak Ridge Anticline, Ventura Basin, Southern California. Geological Society of America Bulletin, v. 114, n. 6, p. 745-53, 2002. https://pubs.geoscienceworld.org/gsaBulletin/article/114/6/745-753/183882.

BARBOSA, M.E.F.; FURRIER, M. Análise de bacia hidrográfica como subsídio para detecção de neotectônica: estudo da bacia hidrográfica do Rio Guruji, litoral sul do estado da Paraíba. Cadernos de Geociências, v. 8, n. 1, p. 10-18, 2011. 
BARBOSA, T.S.; LIMA, V.F.; FURRIER, M. Anomalias em padrões de drenagem como fator de verificação de neotectônica - um estudo de caso nas sub-bacias do Rio Mamuaba-PB. Revista do Departamento de Geografia, v. 26, p. 195-213, 2013. https://doi.org/10.7154/RDG.2013.0026.0010

BARBOSA, T.S.; FURRIER, M. Aplicação de Índices Morfométricos para Análise Geomorfológica e Neotectônica da Bacia do Rio Marés - PB, Brasil. Geografia (Londrina), v. 26, n. 2. p. 23-38, 2017. http://www.uel.br/revistas/uel/index.php/geografia/article/view/25528.

BARROS, L.F.P.; BARROS, P.H.C.A.; MAGALHÃES JR., A.P. Condicionamento litológico e tectônico na morfometria da bacia do Rio Conceição - Quadrilátero Ferrífero/MG. Revista de Geografia (Recife), volume especial, n. 1, p. 195-209, 2010a. https://doi.org/10.51359/2238-6211.2010.228848

BARROS, L.F.P.; MAGALHÃES JR., A.P.; RAPOSO, A.A. Fatores condicionantes da produção e escoamento de sedimentos na bacia do Rio Maracujá - Quadrilátero Ferrífero/MG. Geografias (UFMG), v. 6, n. 2, p. 102-117, 2010b.

BARROS, L.F.P.; REIS, R.A.P. A produção científica em geomorfologia fluvial na Revista Brasileira de Geomorfologia: panorama bibliográfico, tendências e lacunas. Revista Brasileira de Geomorfologia, v. 20, p. 673-680, 2019. http://www.lsie.unb.br/rbg/index.php/rbg/article/view/1553.

BRASIL. Ministério da Agricultura e Reforma Agrária. Secretaria Nacional de Irrigação. Departamento Nacional de Meteorologia. Normais climatológicas (1961-1990). Brasília: 1992. 84p.

BRITO-NEVES, B.B.; ALKMIM, F.F. Cráton: Evolução de um conceito. In: MISI, J.M.L.; DOMINGUEZ, A. (eds.). O Cráton do São Francisco. Salvador: SBG, 1993. p. 1-10.

BULL, W.B.; MCFADDEN, L. D. Tectonic Geomorphology of North and South of the Garlock Fault, California. In: DOHRING, D. O. (Ed.). Geomorphology in Arid Regions. Binghamton: State University of New York, 1977. p. 115-138.

BURBANK, D.W.; ANDERSON, R.S. 2001. Tectonic Geomorphology. Oxford: Blackwell Science. 2001.

CAMOLEZI, B.A.; FORTES, E.; MANIERI, D.D. Controle estrutural da rede de drenagem com base na correlação de dados morfométricos e morfoestruturais: o caso da bacia do Ribeirão São Pedro - Paraná. Revista Brasileira de Geomorfologia, v.13, n.2, p.201-211, 2012. http://dx.doi.org/10.20502/rbg.v13i2.267

CAMPOS, J.E.G.; DARDENNE, M.A. Estratigrafia e sedimentação da Bacia Sanfranciscana: uma revisão. Revista Brasileira de Geociências, v. 27, n. 3, p. 269-82, 1997a.

CAMPOS, J.E.G.; DARDENNE, M.A. Origem e evolução tectônica da Bacia Sanfranciscana. Revista Brasileira de Geociências, v. 27, n. 3, p. 283-294, 1997 b.

CANNON, P. J. Generation of explicit parameters for a quantitative geomorphic study of the Mill Creek Drainage Basin. Oklahoma Geology Notes, v. 36, n. 1, p. 3-17, 1976.

CETEC, Fundação Centro Tecnológico de Minas Gerais. $2^{\circ}$ plano de desenvolvimento integrado do noroeste mineiro: recursos naturais. Belo Horizonte: CETEC, 1981.

CETEC, Fundação Centro Tecnológico de Minas Gerais. Diagnóstico Ambiental do Estado de Minas Gerais. Belo Horizonte: CETEC, 1983.

CHANG, H.K.; MIRANDA, F.P.; DELLA PIAZA, H.; FREITAS, E.L.; CASTRO, J.C.; BABINSKI, N.A.; QUADROS, L.P.; GONÇALVES, A.; MELLO, U. GUAZELLI, W. 1987. Bacia do São Francisco: PréCambriano Brasileiro com Hidrocarbonetos. Boletim de Geociências da Petrobrás, v. 1, n. 2, p. 235-36. 1987. 
CHEREM, L.F.S.; MAGALHÃES JR, A.P.; FARIA, S.D. Análise e compartimentação morfométrica da bacia hidrográfica do Alto Rio das Velhas - Região Central de Minas Gerais. Revista Brasileira de Geomorfologia, v.12, n.1, p.11-21, 2011. http://dx.doi.org/10.20502/rbg.v12i1.214

COMPANHIA DE PESQUISA DE RECURSOS MINERAIS; COMPANHIA MINERADORA DE MINAS GERAIS. Mapa geológico: Folha João Pinheiro. 1:250.000. Projeto São Francisco. Belo Horizonte, CPRM; COMIG, 2003a.

COMPANHIA DE PESQUISA DE RECURSOS MINERAIS; COMPANHIA MINERADORA DE MINAS GERAIS. Mapa geológico: Folha São Romão. 1:250.000. Projeto São Francisco. Belo Horizonte, CPRM; COMIG, 2003b.

CONRAD, O.; BECHTEL, B.; BOCK, M.; DIETRICH, H.; FISCHER, E.; GERLITZ, L.; WEHBERG, J.; WICHMANN, V.; AND BÖHNER, J. (2015): System for Automated Geoscientific Analyses (SAGA) v. 2.1.4, Geoscientific Model Development, 8, 1991-2007. Doi:10.5194/gmd-8-1991-2015. https://gmd.copernicus.org/articles/8/1991/2015/.

COX, R.T. Analysis of drainage-basin symmetry as a rapid technique to identify areas of possible Quaternary tilt-block tectonics: an example from the Mississippi embayment. Geological Society of

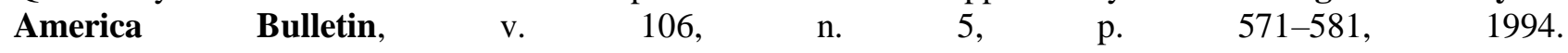
https://pubs.geoscienceworld.org/gsaBulletin/article/106/5/571-581/182937.

DARDENNE, M.A. Síntese sobre a estratigrafia do Grupo Bambuí no Brasil Central. In: Congresso Brasileiro de Geologia, 30; 1978, Recife. Proceedings... Recife: SBG, 1978. p. 507-610.

DEMOULIN, A. Basin and River Profile Morphometry: A New Index with a High Potential for Relative Dating of Tectonic Uplift. Geomorphology, v. 126, n. 1-2, p. 97-107. 2011. https://linkinghub.elsevier.com/retrieve/pii/S0169555X1000471X.

EL HAMDOUNI R., IRIGARAY C., FERNÁNDEZ T., CHACÓN J., Keller E.A. Assessment of relative active tectonics, southwest border of the Sierra Nevada (southern Spain). Geomorphology, v. 96, n. 1-2, p. 150-173, abr. 2008. http://linkinghub.elsevier.com/retrieve/pii/S0169555X07003893.

ETCHEBEHERE, M. L. C.; SAAD, A. R.; SANTONI, G. C.; CASADO, F. C.; FULFARO, V. J. Detecção de prováveis deformações neotectônicas no vale do Rio do Peixe, região ocidental paulista mediante aplicação de índices RDE (Relação Declividade-Extensão) em segmentos de drenagem. Revista de Geociências USP, v. 25, p. 271-289, 2006.

FUJITA, R.H.; GON, P.P.; STEVAUX, J.C.; SANTOS, M.L.; ETCHEBEHERE, M.L. Perfil longitudinal e a aplicação do índice de gradiente (RDE) no rio dos Patos, bacia hidrográfica do rio Ivaí, PR. Revista Brasileira de Geociências, v. 41, n. 4, p. 597-603, $\operatorname{dez.} 2011$. http://ppegeo.igc.usp.br/index.php/rbg/article/view/7856/7283.

FULFARO, V.J.; ETCHEBEHERE, M.L.; SAAD, A.R.; PERINOTTO, J.A.J. The Araras Escarpment in the upper Paraná River: implications to fluvial neotectonics on the Paraná drainage net evolution. Revista Brasileira de Geomorfologia, v.6, n. 1, p. 115-122, 2005.

GIAMBONI, M.; WETZEL, A.; SCHNEIDER, B. Geomorphic Response of Alluvial Rivers to Active Tectonics: Example from the Southern Rhinegraben. Austrian Journal of Earth Sciences, v. 97, p. 24-37, 2005.

GONTIJO-PASCUTTI, A.H.F.; BEZERRA, F.H.R.; TERRA, E.; ALMEIDA, J.C.H. Brittle reactivation of mylonitic fabric and the origin of the Cenozoic Rio Santana Graben, southeastern Brazil. Journal of South American Earth Sciences, v. 29, p. 522-536, 2010. https://doi.org/10.1016/j.jsames.2009.06.007.

GRASS GIS community. GRASS GIS software repository. Available in: https://grass.osgeo.org/about/community/ Access in: Jan, 182021. 
GROHMANN, C.H. 2004. Morphometric analysis in Geographic Information Systems: applications of free software GRASS and R. Computers \& Geosciences, v. 30, p. 1055-1067, 2004. https://linkinghub.elsevier.com/retrieve/pii/S0098300404001402.

GROHMANN, C.H.; RICCOMINI, C.; CHAMANI, M.A.C. Regional scale analysis of landform configuration with base-level (isobase) maps. Hydrology and Earth System Science, v. 15, p. 1493-1504, 2011. https://hess.copernicus.org/articles/15/1493/2011/.

GROHMANN, C.H.; RICOMINNI, C.; ALVES, F.M. 2007. SRTM-based morphotectonic analysis of the Poços de Caldas Alkaline Massif, southeastern Brazil. Computer \& Geosciences, v. 33, p. 10-19, 2007. https://linkinghub.elsevier.com/retrieve/pii/S009830040600080X.

GROHMANN, C.H.; SMITH, M.J.; RICCOMINI, C. Multi-scale Analysis of Topographic Surface Roughness in the Midland Valley, Scotland. IEEE Transactions on Geoscience and Remote Sensing, v. 49, p. 1200-1213, 2001. https://doi.org/10.1109/TGRS.2010.2053546.

HACK, J.T. Stream-Profile Analysis and Stream-Gradient Index. Journal Research of the U.S. Geological Survey, v. 1, n.4, p. 421-29. 1973.

HARE, P.H.; GARDNER, T. W. Geomorphic indicators of vertical neotectonism along converging plate margins, Nicoya Peninsula, Costa Rica. In: MORISAWA, M., Hack, J.T. (eds.). Tectonic Geomorphology: Proceedings of the 15th Annual Binghamton Geomorphology Symposium. London: Allen \& Unwin, 1985. p. 75-104.

HAREL, E.; GOREN, L.; SHELEF, E.; GINAT, H. Drainage Reversal toward Cliffs Induced by Lateral Lithologic Differences. Geology, v. 47, n. $10, \quad$ p. $928-32 . \quad 2019$. https://pubs.geoscienceworld.org/gsa/geology/article/47/10/928/573170/Drainage-reversal-toward-cliffsinduced-by-lateral.

HASUI, Y. Neotectônica e aspectos fundamentais da tectônica ressurgente no Brasil. I Workshop sobre Neotectônica e Sedimentação Cenozoica Continental no Sudeste Brasileiro. 1., 1990. Belo Horizonte. Proceedings... Belo Horizonte: SBG-Núcleo Minas Gerais. 1990. p. 1-31.

HIRUMA, S.T.; PONÇANO, W.L. Densidade de drenagem e sua relação com fatores geomorfopedológicos na área do alto rio Pardo, SP e MG. Revista do Instituto Geológico, v. 15, n. 1/2, p. 49-57, 1994. http://dx.doi.org/10.5935/0100-929X.19940005.

HORTON, R. E. Erosional development of streams and their drainage basin: Hydro-physical approach to quantitative morphology. Geological Society of America Bulletin, v. 56, n. 3, p. 275-370, 1945. https://doi.org/10.1130/0016-7606(1945)56[275:EDOSAT]2.0.CO;2.

HORTON, R.E. Drainage-Basin Characteristics. Transactions, American Geophysical Union, v. 13, n, 1, p. 350-62. 1932. http://doi.wiley.com/10.1029/TR013i001p00350.

KELLER, E.A.; PINTER, N. Active Tectonics, Earthquakes, Uplift and Landscape. 2nd Edition, Prentice Hall, Upper Saddle River, 2002.

LIMA, V.F.; FURRIER, M. Influência neotectônica identificada através de dados morfométricos e morfológicos-um estudo de caso nas bacias dos Rios Vermelho e do Buraco-PB. Revista Eletrônica Geoaraguaia, v. 4, n.1, p $29-49,2014$.

MAGALHÃES JR, A.P.; SAADI, A. Ritmos da dinâmica fluvial neo-cenozoica controlados por soerguimento regional e falhamento: o vale do Rio das Velhas na Região de Belo Horizonte, Minas Gerais, Brasil. Geonomos, v.2, n.1, p.42-54, 1994. http://dx.doi.org/10.18285/geonomos.v2i1.231.

MANJORO, M. Structural Control of Fluvial Drainage in the Western Domain of the Cape Fold Belt, South Africa. Journal of African Earth Sciences, v. 101, p. 350-59, 2015. https://linkinghub.elsevier.com/retrieve/pii/S1464343X14003318. 
MARENGO, J.A. LIEBMANN, B.; GRIMM, A.M. MISRA, V.; Silva DIAS, P.L.; CAVALCANTI, I.F.A.; CARVALHO, L.M.V.; BERBERY, E.H.; AMBRIZZI, T.; VERA, C.S.; SAULO, A.C.; NOGUESPAEGLE, J.; ZIPSER, E.; SETH, A.; ALVES, L.M. Recent developments on the South American monsoon system. International Journal of Climatology, v. $32, \quad$ n. $1, \quad$ p. $1-21, \quad 2012$. http://doi.wiley.com/10.1002/joc.2254.

MARPLE, R.T.; TALWANI, P. Evidence of Possible Tectonic Upwarping along the South Carolina Coastal Plain from an Examination of River Morphology and Elevation Data. Geology, v. 21, p. 651-54, 1993. https://doi.org/10.1130/0091-7613(1993)021\%3C0651:EOPTUA\%3E2.3.CO;2.

MARQUES NETO, R.; PEREZ FILHO, A. Análise morfoestrutural e morfotectônica da bacia do Rio Capivari, sul de Minas Gerais: a neotectônica e as superfícies geomorfológicas. Revista Brasileira de Geomorfologia, v.14, n.4, p.271-277, 2013. http://dx.doi.org/10.20502/rbg.v14i4.178.

MARQUES NETO, R.; PEREZ FILHO, A. Compartimentação morfoestrutural da bacia do Rio Verde, sul de Minas Gerais. Revista Brasileira de Geomorfologia, v.15, n.1, p.119-135, 2014. http://dx.doi.org/10.20502/rbg.v14i4.178.

MENDES, L.D.; FERNANDES, N.F.; GONTIJO-PASCUTTI, A.H.F. Morfotectônica da bacia hidrográfica do Rio Bonito, Petrópolis, RJ. Revista Brasileira de Geomorfologia, v.8, n.1, p.63-77, 2007. http://dx.doi.org/10.20502/rbg.v8i1.86.

NIMER, E. Clima. In: Fundação Instituto Brasileiro de Geografia. Geografia do Brasil. Região Sudeste. Rio de Janeiro, SERGRAF/IBGE, 1957. v. 3. p. 51-89.

NTOKOS, D.; LYKOUDI, E.; RONDOYANNI, T. Geomorphic analysis in areas of low-rate neotectonic deformation: South Epirus (Greece) as a case study. Geomorphology, v. 263, p. 156-169, 2016. https://linkinghub.elsevier.com/retrieve/pii/S0169555X16301647.

OLIVEIRA, V.F.; SILVA FILHO, W.F.; NOGUEIRA NETO, J.A. Atividade neotectônica na borda norte da Bacia do Araripe (Ceará-Brasil): evidências a partir de índices morfométricos. Geociências, v. 37, n. 3, p. 523-541, 2018.

OUCHI, S. Response of Alluvial Rivers to Slow Active Tectonic Movement. Geological Society of

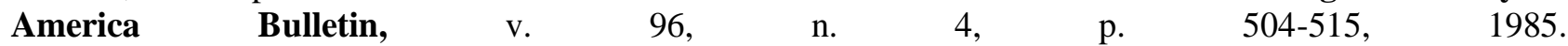
https://pubs.geoscienceworld.org/gsaBulletin/article/96/4/504-515/190605.

PAES, T.V.; SILVA, T.M. Indicadores geomorfológicos de controles litológicos e/ou estruturais - bacia do Rio Guapi-Açu, cachoeiras de Macacu (RJ). Revista de Geografia PPGEO-UFJF, v. 7, n. 2, p. 107-123, 2017. https://doi.org/10.34019/2236-837X.2017.v7.18061.

PEDRERA, A., PÉREZ-PEÑA, J.V., GALINDO-ZALDÍVAR, J., AZAÑóN, J.M., AZOR, A. Testing the sensitivity of geomorphic indices in areas of low-rate active folding (eastern Betic Cordillera, Spain).

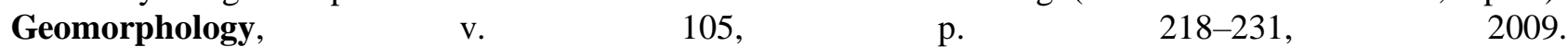
http://linkinghub.elsevier.com/retrieve/pii/S0169555X08004510.

PEDROSA-SOARES, A.C.; DARDENNE, M.A.; HASUI, Y.; CASTRO, F.D.C.; CARVALHO, M.V.A. Nota explicativa dos mapas Geológico, Metalogenético e de Ocorrências Minerais do Estado de Minas Gerais, escala 1:1.000.000. Belo Horizonte: CPRM: COMIG, 1994.

PÉREZ-PEÑA, J. V.; AZOR, Z.; AZAÑÓN, J.M.; Keller, E.A. Active tectonics in the Sierra Nevada (Betic Cordillera, SE Spain): Insights from geomorphic indexes and drainage pattern analysis. Geomorphology, v. 119, n. 1-2, p. 74-87, jun. 2010. http://linkinghub.elsevier.com/retrieve/pii/S0169555X10001042.

PERUCCA, L.P., ROTHIS, M.; VARGAS, H.N. Morphotectonic and Neotectonic Control on River Pattern in the Sierra de La Cantera Piedmont, Central Precordillera, Province of San Juan, Argentina. Geomorphology, v. 204, p. 673-82, 2014. https://linkinghub.elsevier.com/retrieve/pii/S0169555X13004728. 
PEYERL, W.R.L.; SALAMUNI, E.; SANCHES, E.; NASCIMENTO, E.R.; SANTOS, J.M.; GIMENEZ, V.B.; SILVA, C.L.; FARIAS, T.F.S. Reativation of Taxaquara Fault and its morphotectonic influence on the evolution of Jordão River catchment, Paraná, Brazil. Brazilian Journal of Geology, v. 48, n. 3, p. 553-573, 2018. https://doi.org/10.1590/2317-4889201820170110.

PINTO, R.W.P.; FREITAS, M.M.; ALMEIDA, J.C.H.; SILVA, L.G.A.E. Evolução geomorfológica do Rio Grande, RJ: influências geológicas e capturas de drenagem. Revista Brasileira de Geomorfologia (Online), v.19, n.2, p.407-422, 2018. http://dx.doi.org/10.20502/rbg.v19i2.972.

QGIS Development Team. QGIS Geographic Information System (versão 3.14). Open Source Geospatial Foundation Project, 2021. Disponível em: http://qgis.osgeo.org.

RAMÍREZ-HERRERA, M. T. Geomorphic assessment of active tectonics in the Acambay graben, Mexican Volcanic Belt. Earth Surface Processes and Landforms, v. 23, n. 4, p. 317-332, 1998. https://doi.org/10.1002/(SICI)1096-9837(199804)23:4<317::AID-ESP845>3.0.CO;2-V

REIS, H.L.S.; ALKMIM, F.F.; FONSECA, R.C.S.; NASCIMENTO, T.C.; SUSS, J.F.; PREVATTI, L.D. The São Francisco Basin. In: HEILBRON, M.; CORDANI, U.G.; ALKMIM, F.F. São Francisco Craton, Eastern Brazil: tectonic genealogy of a miniature continent. Switzerland: Springer, 2017. p. $117-43$. http://link.springer.com/10.1007/978-3-319-01715-0_7.

RHEA, S. Evidence of Uplift near Charleston, South Carolina. Geology, v. 17, p. 311-315, 1989. https://doi.org/10.1130/0091-7613(1989)017<0311:EOUNCS>2.3.CO;2

ROCKWELL T.K.; KELLER, E.A.; JOHNSON, D.L. Tectonic geomorphology of alluvial fans and mountain fronts near Ventura, California. In MORISAWA M. (ed.). Tectonic Geomorphology. Boston: Allen and Unwin Publishers, 1985. p. 183-207.

ROSSETTI, D.F.; GÓES, A.M.; VALERIANO, M.M.; MIRANDA, M.C.C. Quaternary Tectonics in a Passive Margin: Marajó Island, Northern Brazil. Journal of Quaternary Science, v. 23, n. 2, p. $121-35$. 2008. http://doi.wiley.com/10.1002/jqs.1132.

SAADI, A. A geomorfologia da Serra do Espinhaço em Minas Geras e de suas margens. Geonomos, v. 3, n. 1, p. 41-63, 1995. https://doi.org/10.18285/geonomos.v3i1.215.

SAADI, A. Ensaio sobre a morfotectônica de Minas Gerais: tensões intraplaca, descontinuidades crustais e morfogênese. Tese (Professor Titular) - Instituto de Geociências, Universidade Federal de Minas Gerais, Belo Horizonte. 1991. 285p.

SAJADIAN, M.R.; POURKERMANI, M.; QORASHI, M.; MOGHADDAS, N.H. The Analysis of Transverse Topographic Symmetry Factor (T Index) in the Chekene-Mazavand, North East Iran. Open $\begin{array}{lllllll}\text { Journal of } & \text { Geology, } & \text { v. } & 5, & \text { p. } & 809-820, & 2015 .\end{array}$ http://www.scirp.org/journal/doi.aspx?DOI=10.4236/ojg.2015.511069.

SALAMUN, E.; EBERT, H.D.; HAUI, Y. Morfotectônica da bacia sedimentar de Curitiba. Revista Brasileira de Geociências, v. 34, n. 4, p. 469-478, 2004.

SALVANY, J. M. Tilting neotectonics of the Guadiamar drainage basin, SW Spain. Earth Surface Processes and Landforms, v. 29, n. 2, p. 145-160, 2004. http://doi.wiley.com/10.1002/esp.1005.

SANTOS, D.A.R.; MORAIS, F. Assimetria de bacias hidrográficas e influências litoestruturais na geomorfologia do Rio Formoso, TO. Caminhos de Geografia, v. 18, n. 61, p. 180-199, 2017. http://dx.doi.org/10.14393/RCG186112.

SANTOS, G.B.; CASTRO, P.T.A. Caracterização da Rede de Drenagem e do Sistema Lacustre da Bacia do Rio Grande: Oeste da Bahia. Revista Brasileira de Geomorfologia (Online), v.17, n.4, p.801-818, 2016. http://dx.doi.org/10.20502/rbg.v17i4.870. 
SANTOS, J.A.; SILVA, A.Q.; SOUZA, J.J. Análise morfoestrutural da sub-bacia do rio Alto Paraguai - MT a partir de dados de sensoriamento remoto. In: SIMPÓSIO BRASILEIRO DE SENSORIAMENTO REMOTO, 17.; 2015, João Pessoa. Proceedings... João Pessoa: SBSR-INPE, 2015. p. 4202-4209.

SCHOBBENHAUS, C.; CAMPOS, D.A.; DERZE, G.R.; ASMUS, H.E. (Coords.). Mapa Geológico do Brasil e da área oceânica adjacente incluindo depósitos minerais. Brasília. Departamento Nacional de Produção Mineral, 1985.

SCHOBBENHAUS, C.; CAMPOS, D.A; DERZE, G.R.; ASMUS, H.E. (Coords.). Geologia do Brasil: texto explicativo do mapa geológico do Brasil e da área oceânica adjacente incluindo depósitos minerais. Brasília: Departamento Nacional de Produção Mineral, 1984. 501 p.

SCHUMM, S. A. Evolution of drainage systems and slopes in badlands at Perth Amboy, New Jersey. Geological Society of America Bulletin, v. 67, n. 5, p. 597- 646, 1956.

SEEBER, L.; GORNITZ, V. River profiles along the Himalayan Arc as indicators of active tectonics. Tectonophysics, v. 92, p. 335-367, 1983. https://doi.org/10.1016/0040-1951(83)90201-9.

SGARBI, G.N.C.; SGARBI, P.B.A.; CAMPOS, J.E.G.; DARDENNE, M.A.; PENHA, U.C. Bacia Sanfranciscana: o registro Fanerozoico da bacia do São Francisco. In: PINTO, M.A.; MARTINS-NETO, C.P. Bacia do São Francisco: Geologia e Recursos Naturais. Belo Horizonte: SBG-Núcleo Minas Gerais, 2001. p. 93-138.

SILVA, G.P.R.; ETCHEBEHERE, M.L.; SAAD, A.R.; FRANCO-MAGALHÃES, A.O.B. Análise de Perfis Segmentados de Drenagem Para Avaliação Morfotectônica Na Bacia Hidrográfica Do Alto Rio Jaguari (SPMG). Geociências, v. 31, n. 2, p. 259-71, 2012.

SILVA, P.G.; GOY, J.L.; ZAZO, C.; BARDAJÍ, T. Fault-generated mountain fronts in southeast Spain: geomorphologic assessment of tectonic and seismic activity. Geomorphology, v. 50, p. 203-225, 2003. https://linkinghub.elsevier.com/retrieve/pii/S0169555X02002155.

SMITH K.G. Standards for grading textures of erosional topography. American Journal of Science, v. 48, p. 655-668, 1950. http://www.ajsonline.org/cgi/doi/10.2475/ajs.248.9.655.

SOUGNEZ, N., AND V. VANACKER. The Topographic Signature of Quaternary Tectonic Uplift in the Ardennes Massif (Western Europe). Hydrology and Earth System Sciences, v. 15, n. 4, p. 1095-1107. 2011. https://hess.copernicus.org/articles/15/1095/2011/.

SOUZA, L.S.B.; ROSSETTI, D.F. Caracterização da rede de drenagem na porção leste da ilha do Marajó e implicações tectônicas. Revista Brasileira de Geomorfologia, v. 12, n. 1, p. 2011. http://www.lsie.unb.br/rbg/index.php/rbg/article/view/220.

STRAHLER, A. N. Hypsometric (area-altitude) analysis of erosional topology. Geological Society of America Bulletin, v. 63, n. 11, p. 1117-1142, 1952.

STRAHLER, A. N. Quantitative analysis of watershed geomorphology. Transactions of the American Geophysical Union, v. 8, n. 6, p. 913-920, 1957.

SUKRISTIYANTI, S.; MARIA, R.; LESTIANA, H. Watershed-based Morphometric Analysis: A Review. In: IOP Conference Series: Earth and Environmental Science, 2017; Bandung. Proceedings... Bandung: IOP Conference Series, 2018. p. 1-5. http://doi:10.1088/1755-1315/118/1/012028.

VALADÃO, R.C. Geodinâmica de superfícies de aplanamento, desnudação continental e tectônica ativa como condicionantes da megageomorfologia do Brasil oriental. Revista Brasileira de Geomorfologia, v. 10, n. 2, p. 77-90, 2009. http://www.lsie.unb.br/rbg/index.php/rbg/article/view/132.

VIVEEN, W.; VAN BALEN, R.T.; SCHOORL, J.M.; VELDKAMP, A.; TEMME, A.J.A.M. VIDALROMANI, J.R. Assessment of Recent Tectonic Activity on the NW Iberian Atlantic Margin by Means of Geomorphic Indices and Field Studies of the Lower Miño River Terraces. Tectonophysics, v. 544-545, p. 13-30, 2012. http://linkinghub.elsevier.com/retrieve/pii/S0040195112001849. 
WELLS, S.G., BULLARD, T.F., MENGES, T.M., DRAKE, P.G., KARAS, P.A., KELSON, K.I., RITTER, J.B., WESTLING, J.R. Regional variations in tectonic geomorphology along segmented convergent plate boundary, Pacific coast of Costa Rica. Geomorphology, v. 1, p. 239-265, 1988. http://linkinghub.elsevier.com/retrieve/pii/0169555X88900165.

Este artigo é distribuído nos termos e condições do Creative Commons Attributions/Atribuição-
NãoComercial-CompartilhaIgual (CC BY-NC-SA). 